\title{
Carbon uptake and water use in woodlands and forests in southern Australia during an extreme heat wave event in the "Angry Summer" of 2012/2013
}

\author{
Eva van Gorsel ${ }^{1}$, Sebastian Wolf $^{2}$, James Cleverly $^{3}$, Peter Isaac $^{1}$, Vanessa Haverd ${ }^{1}$, Cäcilia Ewenz $^{4}$, Stefan Arndt ${ }^{5}$, \\ Jason Beringer ${ }^{6}$, Víctor Resco de Dios ${ }^{7}$, Bradley J. Evans ${ }^{8}$, Anne Griebel ${ }^{5,9}$, Lindsay B. Hutley ${ }^{10}$, Trevor Keenan ${ }^{11}$, \\ Natascha Kljun ${ }^{12}$, Craig Macfarlane ${ }^{13}$, Wayne S. Meyer ${ }^{14}$, Ian McHugh ${ }^{15}$, Elise Pendall ${ }^{9}$, Suzanne M. Prober ${ }^{13}$, and \\ Richard Silberstein ${ }^{16}$ \\ ${ }^{1}$ CSIRO, Oceans and Atmosphere, Yarralumla, NSW, 2600, Australia \\ ${ }^{2}$ Department of Environmental Systems Science, ETH Zurich, 8092 Zurich, Switzerland \\ ${ }^{3}$ School of Life Sciences, University of Technology Sydney, Broadway, NSW, 2007, Australia \\ ${ }^{4}$ Airborne Research Australia, Flinders University, Salisbury South, SA, 5106, Australia \\ ${ }^{5}$ School of Ecosystem and Forest Sciences, The University of Melbourne, Richmond, VIC, 3121, Australia \\ ${ }^{6}$ School of Earth and Environment (SEE), The University of Western Australia, Crawley, WA, 6009, Australia \\ ${ }^{7}$ Producció Vegetal i Ciència Forestal, Agrotecnio Centre, Universitat de Lleida, 25198, Lleida, Spain \\ ${ }^{8}$ School of Life and Environmental Sciences, The University of Sydney, Sydney, NSW, 2015, Australia \\ ${ }^{9}$ Hawkesbury Institute for the Environment, Western Sydney University, Penrith, NSW, 2570, Australia \\ ${ }^{10}$ School of Environment, Research Institute for the Environment and Livelihoods, Charles Darwin University, NT, Australia \\ ${ }^{11}$ Lawrence Berkeley National Lab., 1 Cyclotron Road, Berkeley CA, USA \\ ${ }^{12}$ Dept of Geography, College of Science, Swansea University, Singleton Park, Swansea, UK \\ ${ }^{13}$ CSIRO Land and Water, Private Bag 5, Floreat, WA, 6913, Australia \\ ${ }^{14}$ Environment Institute, The University of Adelaide, Adelaide, SA, 5005, Australia \\ ${ }^{15}$ School of Earth, Atmosphere and Environment, Monash University, Clayton, VIC, 3800, Australia \\ ${ }^{16}$ Centre for Ecosystem Management, Edith Cowan University, School of Natural Sciences, Joondalup, WA, 6027, Australia
}

Correspondence to: Eva van Gorsel (evavangorsel@gmail.com)

Received: 9 May 2016 - Published in Biogeosciences Discuss.: 3 June 2016

Revised: 6 October 2016 - Accepted: 14 October 2016 - Published: 1 November 2016

\begin{abstract}
As a result of climate change warmer temperatures are projected through the 21 st century and are already increasing above modelled predictions. Apart from increases in the mean, warm/hot temperature extremes are expected to become more prevalent in the future, along with an increase in the frequency of droughts. It is crucial to better understand the response of terrestrial ecosystems to such temperature extremes for predicting land-surface feedbacks in a changing climate. While land-surface feedbacks in drought conditions and during heat waves have been reported from Europe and the US, direct observations of the impact of such extremes on the carbon and water cycles in Australia have been lacking. During the 2012/2013 summer, Australia experienced a record-breaking heat wave with an exceptional
\end{abstract}

spatial extent that lasted for several weeks. In this study we synthesised eddy-covariance measurements from seven woodlands and one forest site across three biogeographic regions in southern Australia. These observations were combined with model results from BIOS2 (Haverd et al., 2013a, b) to investigate the effect of the summer heat wave on the carbon and water exchange of terrestrial ecosystems which are known for their resilience toward hot and dry conditions. We found that water-limited woodland and energy-limited forest ecosystems responded differently to the heat wave. During the most intense part of the heat wave, the woodlands experienced decreased latent heat flux ( $23 \%$ of background value), increased Bowen ratio $(154 \%)$ and reduced carbon uptake $(60 \%)$. At the same time the forest ecosystem 
showed increased latent heat flux $(151 \%)$, reduced Bowen ratio $(19 \%)$ and increased carbon uptake $(112 \%)$. Higher temperatures caused increased ecosystem respiration at all sites (up to $139 \%$ ). During daytime all ecosystems remained carbon sinks, but carbon uptake was reduced in magnitude. The number of hours during which the ecosystem acted as a carbon sink was also reduced, which switched the woodlands into a carbon source on a daily average. Precipitation occurred after the first, most intense part of the heat wave, and the subsequent cooler temperatures in the temperate woodlands led to recovery of the carbon sink, decreased the Bowen ratio (65\%) and hence increased evaporative cooling. Gross primary productivity in the woodlands recovered quickly with precipitation and cooler temperatures but respiration remained high. While the forest proved relatively resilient to this short-term heat extreme the response of the woodlands is the first direct evidence that the carbon sinks of large areas of Australia may not be sustainable in a future climate with an increased number, intensity and duration of heat waves.

\section{Introduction}

Average temperatures in Australia have increased by $0.9^{\circ} \mathrm{C}$ since 1910 (CSIRO and BOM, 2014), which represents the most extreme of modeling scenarios, and even further warming is projected with climate change (IPCC, 2013). In addition to increased mean temperature, warm temperature extremes are becoming more frequent in Australia and worldwide (Lewis and King, 2015; Steffen, 2015) and an increased prevalence of drought is expected for the future (Dai, 2013). Increases in temperature variability also affect the intensity of heat waves (Schär et al., 2004). Extreme heat and drought often co-occur (King et al., 2014), and soil water limitations can exacerbate the intensity of heat waves (Fischer et al., 2007; Seneviratne et al., 2010) due to reduced evaporative cooling and increased sensible heat flux (Sheffield et al., 2012). This combination of reduced water availability and increased evaporative demand places increased stress on terrestrial ecosystems.

During summer 2012/2013, Australia experienced a record-breaking heat wave that was deemed unlikely without climate change (Steffen, 2015). The Australian summer 2012/2013 was nicknamed the "Angry Summer" or the "Extreme Summer", as an exceptionally extensive and long-lived period of high temperatures affected large parts of the continent in late December 2012 and the first weeks of January 2013 (Bureau of Meteorology, BOM, 2013). Record temperatures were observed in every Australian state and territory, and the record for the hottest daily average temperature $\left(32.4^{\circ} \mathrm{C}\right.$ ) for Australia was recorded on 8 January (Karoly et al., 2013). On the Western Australian south coast, the maximum temperature record was broken in Eucla on 3 Jan- uary with $48.2^{\circ} \mathrm{C}$. In South Australia maximum temperature records were broken at four weather stations between 4 and 6 January. Victoria also observed record heat on 4 January at its south coast in Portland $\left(42.1^{\circ} \mathrm{C}\right)$. In New South Wales record temperatures were recorded on 5 January and were broken again on 19 January, reaching $46.2^{\circ} \mathrm{C}$ before the heat wave subsided. Besides being the hottest year since 1910 , summer 2012/2013 was also considerably drier than average in most parts of the continent, but particularly in the densely populated east of Australia. King et al. (2014) have shown that extreme heat was made much more likely by contributions from the very dry conditions over the inland eastern region of Australia as well as by anthropogenic warming.

Heat waves are becoming hotter, they last longer, and they occur more often (Steffen, 2015). As many ecological processes are more sensitive to climate extremes than to changes in the mean state (Hanson et al., 2006), it is imperative to understand the effect of climate extremes in order to predict the impact on terrestrial ecosystems. Processes and sensitivities differ among biomes, but forests are expected to experience the largest detrimental effects and the longest recovery times from climate extremes due to their large carbon pools and fluxes (Frank et al., 2015). There is increasing evidence that climate extremes may result in a decrease in carbon uptake and carbon stocks (Zhao and Running, 2010; Reichstein et al., 2013). It is therefore crucial to better understand ecosystem responses to climate extremes. The role of climate extremes could be critical in shaping future ecosystem dynamics (Zimmermann et al., 2009), but the sporadic and unpredictable nature of these events makes it difficult to monitor how they affect vegetation through space and time (Mitchell et al., 2014).

Australian forest and woodland ecosystems are strongly influenced by large climatic variability, characterised by recurring drought events and heat waves (Beringer et al., 2016; Mitchell et al., 2014). Eucalyptus regnans ecosystems in southeast Australia, for example, have an exceptional capacity to withstand drought and the ability to recover almost instantly after heat waves (Pfautsch and Adams, 2013). However, drought and heat-related forest die-back events have been observed in southwestern Australia (Matusick et al., 2013; Evans and Lyons, 2013), where drought stress from long-term reductions in rainfall has been exacerbated by short heat wave periods. This suggests that these ecosystems, even though they are resilient to dry and hot conditions, are susceptible to mortality events once key thresholds have been exceeded (Evans et al., 2013). Similar large-scale droughts and heat waves in Europe during 2003 (Ciais et al., 2005), in Canada during 2000 to 2003 (Kljun et al., 2007) and in the US during 2012 (Wolf et al., 2016) caused substantial reductions in summer carbon uptake, and vegetation-climate feedbacks were found to contribute to enhanced temperatures (Teuling et al., 2010; Wolf et al., 2016). However, direct observations of the ecosystem response to large-scale extremes in Australia have been lacking until very recently. 
Table 1. List of OzFlux sites used in this study, abbreviations and site information. MW stands for Mediterranean woodlands, TW for temperate woodlands and TF for temperate forest. MAT and MAP are the mean annual temperature and precipitation for the years 19822013 (BIOS2).

\begin{tabular}{llcccccccc}
\hline ID & Site name & $\begin{array}{c}\text { Latitude } \\
(\mathrm{deg})\end{array}$ & $\begin{array}{c}\text { Longitude } \\
(\mathrm{deg})\end{array}$ & $\begin{array}{c}\text { Elevation } \\
(\mathrm{m})\end{array}$ & $\begin{array}{c}\text { MAT } \\
\left({ }^{\circ} \mathrm{C}\right)\end{array}$ & $\begin{array}{c}\text { MAP } \\
(\mathrm{mm})\end{array}$ & $\begin{array}{c}\text { LAI MODIS } \\
\left(\mathrm{m}^{2} \mathrm{~m}^{-2}\right)\end{array}$ & $\begin{array}{c}\text { Tree height } \\
(\mathrm{m})\end{array}$ & Biome \\
\hline AU-Gin & Gingin & -31.375 & 115.714 & 51 & 18.4 & 681 & 0.9 & 7 & $\mathrm{MW}$ \\
AU-Gww & Great Western Woodlands & -30.192 & 120.654 & 450 & 18.7 & 396 & 0.4 & 25 & MW \\
AU-Cpr & Calperum & -34.004 & 140.588 & 67 & 17.0 & 265 & 0.5 & 4 & $\mathrm{MW}$ \\
AU-Wom & Wombat & -37.422 & 144.094 & 702 & 11.4 & 936 & 4.1 & 25 & $\mathrm{TW}$ \\
AU-Whr & Whroo & -36.673 & 145.029 & 155 & 14.6 & 533 & 0.9 & 30 & $\mathrm{TW}$ \\
AU-Cum & Cumberland Plains & -33.613 & 150.723 & 33 & 17.6 & 818 & 1.3 & 23 & TW \\
AU-Tum & Tumbarumba & -35.657 & 148.152 & 1260 & 9.8 & 1417 & 4.1 & 40 & TF \\
\hline
\end{tabular}

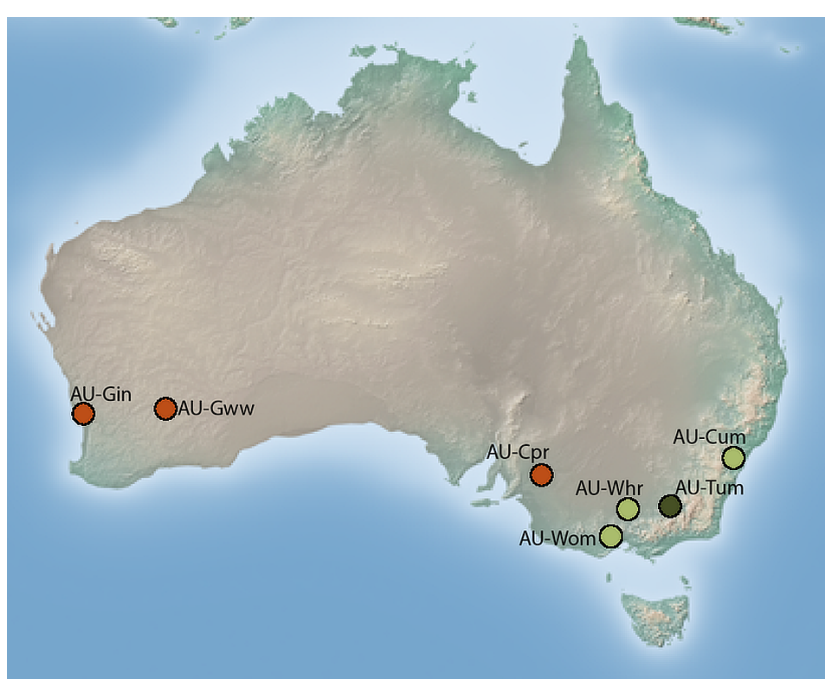

Figure 1. Map indicating the locations of the OzFlux sites used in this study. The sites are grouped into three distinct climate and ecosystem types, indicated by red dots for Mediterranean woodlands (MW), light green dots for temperate woodlands (TW) and a dark green dot for the temperate forest $(\mathrm{TF})$.

The large spatial extent of the heat wave in early 2013 across Australia and direct observations from the OzFlux network enable us for the very first time to analyse the effect of extreme hot and dry conditions on the carbon, water and energy cycles of the major woodland and forest ecosystems across southern Australia. In this study, we combined eddycovariance measurements from seven woodland and forest sites with model simulations from BIOS2 (Haverd et al., 2013a, b) to investigate the impact of the 2012/2013 summer heat wave and drought on the carbon and water exchange of terrestrial ecosystems across climate zones in southern Australia and to assess the influence of land-surface feedbacks on the magnitude of the heat wave.

\section{Materials and methods}

We compared hourly data from seven OzFlux sites (Fig. 1, Table 1), measured during the heat wave period 1-18 January 2013, to observations from a background reference. We used eddy-covariance data to compare hourly data and the daily cycle of latent and sensible heat as well as carbon fluxes. We used the measured hourly data of a background period (BGH) one year later from 2 to 6 January 2014. During these time periods all towers were actively taking measurements, although data gaps were present after 18 January in 2013. The reference period was shorter than the heat wave period because another significant heat wave event affected southeastern Australia in late January 2014 during a time period when not all sites had comparable data available in 2013. Temperatures during the background reference period were also somewhat warmer than average climatology (Fig. 2). We therefore expect the relative severity of the effects of the heat wave to appear smaller than they otherwise would when compared against a climatological reference. To ensure the representativeness of our results, we also compared daily data against a climatology derived from daily BIOS2 (see below) output for the time period 1982-2013 (background climatology, BGC). BIOS2 results for the whole time period were only available as daily values.

\subsection{Sites}

We analysed data from seven southern Australian sites (Beringer et al., 2016), grouped into three distinct ecosystem and climate types: Mediterranean woodlands (MW), temperate woodlands (TW) and temperate forests (TF; Fig. 1, Table 1).

MW sites included (i) a coastal heath Banksia woodland (Gingin: AU-Gin); (ii) a semi-arid eucalypt woodland dominated by Salmon gum (Eucalyptus salmonophloia), with Gimlet (E. salubrious) and other eucalypts (Great Western Woodlands: AU-Gww); and (iii) a semi-arid mallee ecosystem (Calperum: AU-Cpr), which is characterised by an association of mallee eucalypts (E. dumosa, E. incrassata, 


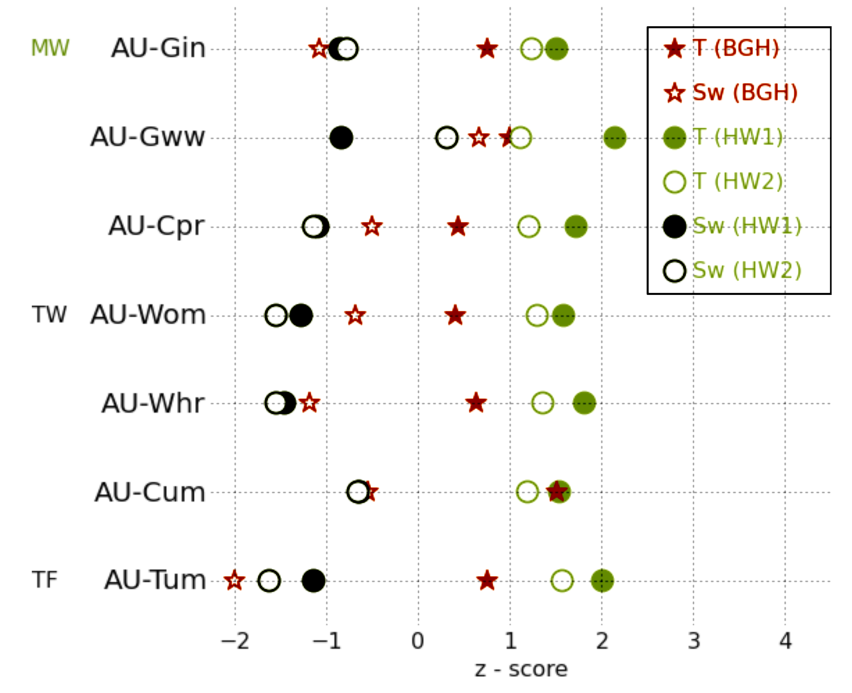

Figure 2. $Z$ scores for temperature and soil water across flux tower sites. Solid red stars denote temperature and unfilled red stars denote soil water scores during the background period $(\mathrm{BGH})$ compared to the climatological background BGC. Scores for temperature $(T)$ and soil water ( $\mathrm{Sw}$ ) for HW1 and HW2 compared to the same time periods in the years 1982-2013 are shown for HW1 (1-9 January 2013) by filled dots and for HW2 (10-18 January 2013) by unfilled dots.

E. oleosa and E. socialis) and spinifex hummocks (Triodia basedowii; Sun et al., 2015; Meyer et al., 2015). TW sites are classified as dry sclerophyll woodlands and include the following: (i) Wombat (AU-Wom), a secondary re-growth of Messmate Stringybark (E. oblique), NarrowLeaved Peppermint (E. radiate) and Candlebark (E. rubida); (ii) Whroo (AU-Whr), a box woodland mainly composed of Grey Box (E. microcarpa) and Yellow Gum (E. leucoxylon) with smaller numbers of Ironbark (E. sideroxylon) and Golden Wattle (Acacia pycnantha); (iii) Cumberland Plains (AU-Cum), where the canopy is dominated by Gumtopped Box (E. moluccana) and Red Ironbark (E. fibrosa), which host an expanding population of mistletoe (Amyema miquelii). Temperate Forests (TF) are represented by the Tumbarumba site (AU-Tum), which is in a wet sclerophyll forest dominated by Alpine Ash (E. delegatensis) and Mountain Gum (E. dalrympleana; Leuning et al., 2005).

The sites fall into the classifications "Mediterranean forests, woodland and scrub" (AU-Gin, AU-GWW and AUCpr) or the "temperate broadleaf and mixed forest" (AUWom, Au-Cum, AU-Whr and AU-Tum) classifications of IBRA (Interim Biogeographic Regionalisation for Australia v. 7; Environment, 2012). In temperate Australia both woodlands and forests are mainly dominated by Eucalyptus species. Forests occur in the higher rainfall regions and woodlands form the transitional zone between forests and grass-shrublands of the drier interior. We therefore classified temperate ecosystems with mean annual precipitation
$>1000 \mathrm{~mm}$ and tree height $>30 \mathrm{~m}$ as forests. There was only one temperate, wet sclerophyll forest for which data were available during this heat wave, but we are confident that it is representative of the energy-limited temperate forests of southern Australia (e.g. van Gorsel et al., 2013). None of the sites is continental, but elevations range from 33(AUCum) to $1260 \mathrm{~m}$ a.s.l. (AU-Tum). The mean annual temperature for the years $1982-2013$ ranged from $9.8^{\circ} \mathrm{C}$ in $\mathrm{AU}-$ Tum to $18.7^{\circ} \mathrm{C}$ in AU-Gww (Table 1). Mean annual precipitation also covered a large range from 265 in AU-Cpr to $1417 \mathrm{~mm} \mathrm{yr}^{-1}$ in AU-Tum.

\subsection{OzFlux data}

We analysed data collected by the OzFlux network (www. OzFlux.org.au). Each site has a set of eddy-covariance (EC) instrumentation, consisting of an infrared gas analyser (LI7500 or LI-7500A, LI-COR, Lincoln, NE, USA) and a 3-D sonic anemometer (generally a CSAT3 (Campbell Scientific Instruments, Logan, UT, USA) except for AU-Tum, where a Gill-HS is operational; Gill Instruments, Lymington, UK). Supplementary meteorological observations include radiation (4 component CNR4 or CNR1, Kipp and Zonen, Delft, Netherlands) and temperature and humidity (HMP45C or HMP50, Vaisala, Helsinki, Finland). Soil volumetric water content was measured with CS616 (Campbell Scientific). EC data were processed using the OzFlux-QC processing tool (Isaac et al., 2016). Processing steps and corrections included outlier removal, coordinate rotation (double rotation), frequency attenuation correction, conversion of virtual heat flux to sensible heat flux, and the WPL correction (Tanner and Thurtell, 1969; Wesley, 1970; Webb et al., 1980; Schotanus et al., 1983; Lee et al., 2004, and references therein). Friction velocity thresholds were calculated following the method of Barr et al. (2013). In Tumbarumba, where advection issues are known (van Gorsel et al., 2007; Leuning et al., 2008), only data from the early evening were used during nighttime hours (van Gorsel et al., 2009). Gaps in the meteorological time series were filled using alternate data sets, BIOS2 or ACCESS (Australian Community Climate and Earth-System Simulator) output (Bi et al., 2013) or climatologies (usually in this order of preference). Gaps in the flux time series were filled using a self-organising linear output model (SOLOSOFM, Hsu et al., 2002; Abramowitz et al., 2006, and references therein). The OzFlux data used in this analysis are available from http://data.ozflux.org.au/portal/.

\subsection{BIOS2}

The coupled carbon and water cycles were modelled using BIOS2 (Haverd et al., 2013a, b) constrained by multiple observation types, and forced using remotely sensed vegetation cover and daily AWAP meteorology (Raupach et al., 2009), downscaled to half-hourly time resolution using a weather generator. BIOS2 is a fine-spatial-resolution $\left(0.05^{\circ}\right)$ offline 
modeling environment, including a modification of the CABLE biogeochemical land surface model (Wang et al., 2010, 2011) incorporating the SLI soil model (Haverd and Cuntz, 2010). BIOS2 parameters are constrained and predictions are evaluated using multiple observation sets from across the Australian continent, including streamflow from 416 gauged catchments, eddy flux data $\left(\mathrm{CO}_{2}\right.$ and $\left.\mathrm{H}_{2} \mathrm{O}\right)$ from 14 OzFlux sites (Haverd et al., 2016), litterfall data, and soil, litter and biomass carbon pools (Haverd et al., 2013a). In this work, we updated BIOS2 to use the GIMMS3g FAPAR product (Zhu et al., 2013) instead of MODIS and AVHRR products for prescribed vegetation cover (Haverd et al., 2013b). The reference period used for BIOS2 (BGC) was 1982-2013, the period over which remotely sensed data were available.

\subsection{Analyses}

All data analyses were performed on Jupyter notebooks using Python 2.7.11 and the Anaconda (4.0.0) distribution by Continuum Analytics. Differences between heat waves and reference periods were determined by calculating $z$ scores of temperatures and soil water content during the relevant periods. The $z$ scores represent the number of standard deviations an observation is above or below the mean, depending upon the sign of the $z$ score. These were calculated with the $z$ score function of the scipy.stats module for the period 1-18 January relative to the mean across all years in the BIOS2 output (1982-2013). The scipy stats functions bartlett and ttest_ind were used to determine the significance of differences of a range of variables between the background period (BGH or BGC) and the heat wave periods HW1 (1-9 January 2013) and HW2 (HW2, 10-18 January 2013). Boxplots were created using Matplotlib.

\subsection{Conventions}

We use the terminology and concepts as introduced by Chapin et al. (2006), where net and gross carbon uptake by vegetation (net ecosystem production (NEP) and gross primary production; GPP) are positive directed toward the surface and carbon loss from the surface to the atmosphere (ecosystem respiration; ER) is positive directed away from the surface.

\section{Results}

\subsection{Heat wave characterisation}

The heat wave event commenced on 25 December 2012 with a build-up of extreme heat in the southwest of Western Australia. A high-pressure system in the Great Australian Bight and a trough near the west coast directed hot easterly winds over the area (BOM, 2013). From 31 December the high pressure system started moving eastward, and it entered the Tasman Sea off eastern Australia on 4 January. The northerly winds directed very hot air into southeastern Australia. Temporary cooling was observed in the eastern states after 8 January, but a second high pressure system moved into the bight in the meantime, starting a second wave of record-breaking heat across the continent. The heat wave finally ended on 19 January, when southerly winds brought cooler air masses to southern Australia.

Figure 3 shows the meteorological conditions at the sites during the heat wave. Maximum temperatures as high as $46.3{ }^{\circ} \mathrm{C}$ were accompanied by vapour pressure deficits up to $9.7 \mathrm{kPa}$. The soil water fraction was as low as 0.02 in MW but increased to 0.05 and 0.4 at $\mathrm{AU}-\mathrm{Gin}$ and $\mathrm{AU}-\mathrm{Gww}$ respectively after synoptic rainfalls around 12 January. The same, but less pronounced, was also the case for the TW sites where soil water fractions increased from 0.10 to 0.18 after rain. At the TF site, Au-Tum, soil water content decreased throughout the heat wave (HW) from 0.26 to 0.19 . Due to intermittent precipitation events we analysed two parts of the heat wave separately: heat wave period 1 (HW1, 1-9 January 2013) was characterised by very little precipitation $(2 \mathrm{~mm}$ over all sites) and low soil water content. During heat wave period 2 (HW2, 10-18 January 2013) precipitation occurred at most sites (12-15 January 2013) and resulted in increased soil water content at some sites and lower temperature anomalies at all sites than during HW1.

During HW1 temperatures were generally more than 1.52 standard deviations $(\sigma)$ higher than the 32-year mean of the background period (BGC) for these dates. At AU-Tum and AU-Gww $z$ scores exceeded $+2 \sigma$. During HW2 all sites showed lower $z$ scores for temperature, but they were still more than $+1 \sigma$ higher than average background temperatures. The background period BGH, against which we compare the hourly data of the heat wave, was also warmer than average conditions during the past 30 years, but these $z$ scores were well below 1 for most sites.

The $z$ values indicate that soil water content was unusually low for the time of year. It was mostly more than one standard deviation below average $(\sigma<-1)$, except at AUGww where soil water content was higher than average during HW2. All sites except AU-Gin and AU-Gww had a lower $z$ score for soil water content during HW2 than HW1, indicating relatively drier conditions with respect to the BIOS2 derived climatology despite the presence of rainfall during HW2. The background period BGH was generally less dry than the heat wave periods, one noteworthy exception being AU-Tum, which had very dry conditions $(-2 \sigma)$ in BGC during early January 2014. The $z$ scores indicate that high temperatures were more unusual than low soil water content during HW1. HW2 was both hot and dry. 
Table 2. Statistics of radiation and energy exchange for the ecosystems Mediterranean woodlands (MW), temperate woodlands (TW) and temperate forests (TF) and the variables flux of shortwave downward radiation (Fsd), shortwave upward radiation (Fsu), longwave downward radiation (Fld), longwave upward radiation (Flu), net radiation (Fn), latent heat (Fe), sensible heat (Fh), ground heat (Fg) and the energy imbalance $(\varepsilon)$. Where values during the two periods of the heat wave ( $\Delta \mathrm{HW} 1$ and $\Delta \mathrm{HW}$ ) differ significantly from the background (BGH; $P<0.1)$ this is indicated by bold fonts.

\begin{tabular}{|c|c|c|c|c|c|c|c|c|c|c|c|c|c|c|c|c|c|c|c|c|c|c|c|c|c|c|c|}
\hline & MW & TW & TF & MW & TW & $\mathrm{TF}$ & MW & TW & TF & MW & TW & $\mathrm{TF}$ & MW & TW & TF & MW & TW & $\mathrm{TF}$ & MW & TW & $\mathrm{TF}$ & MW & TW & $\mathrm{TF}$ & MW & TW & $\mathrm{TF}$ \\
\hline & & Fsd & & & Fsu & & & Fld & & & Flu & & & Fn & & & $\mathrm{Fe}$ & & & Fh & & & $\mathrm{Fg}$ & & & $\varepsilon$ & \\
\hline BGH & 335 & 264 & 293 & 49 & 30 & 31 & 350 & 383 & 323 & 439 & 444 & 387 & 197 & 175 & 197 & 38 & 63 & 103 & 130 & 90 & 55 & 5 & 1 & 0 & 24 & 21 & 39 \\
\hline$\Delta \mathrm{HW} 1$ & -10 & 4 & 70 & -1 & 0 & 3 & 38 & 9 & 0 & 49 & 33 & 41 & -19 & -20 & 26 & -12 & 2 & 52 & -5 & 30 & -8 & 6 & 4 & 5 & -8 & -56 & -23 \\
\hline$\Delta \mathrm{HW} 2$ & -62 & 20 & 16 & -10 & 2 & 14 & 36 & 2 & -13 & 19 & 16 & 12 & -35 & 3 & -8 & -3 & -2 & 14 & -29 & -4 & -8 & -5 & 1 & 0 & 1 & 8 & -14 \\
\hline
\end{tabular}
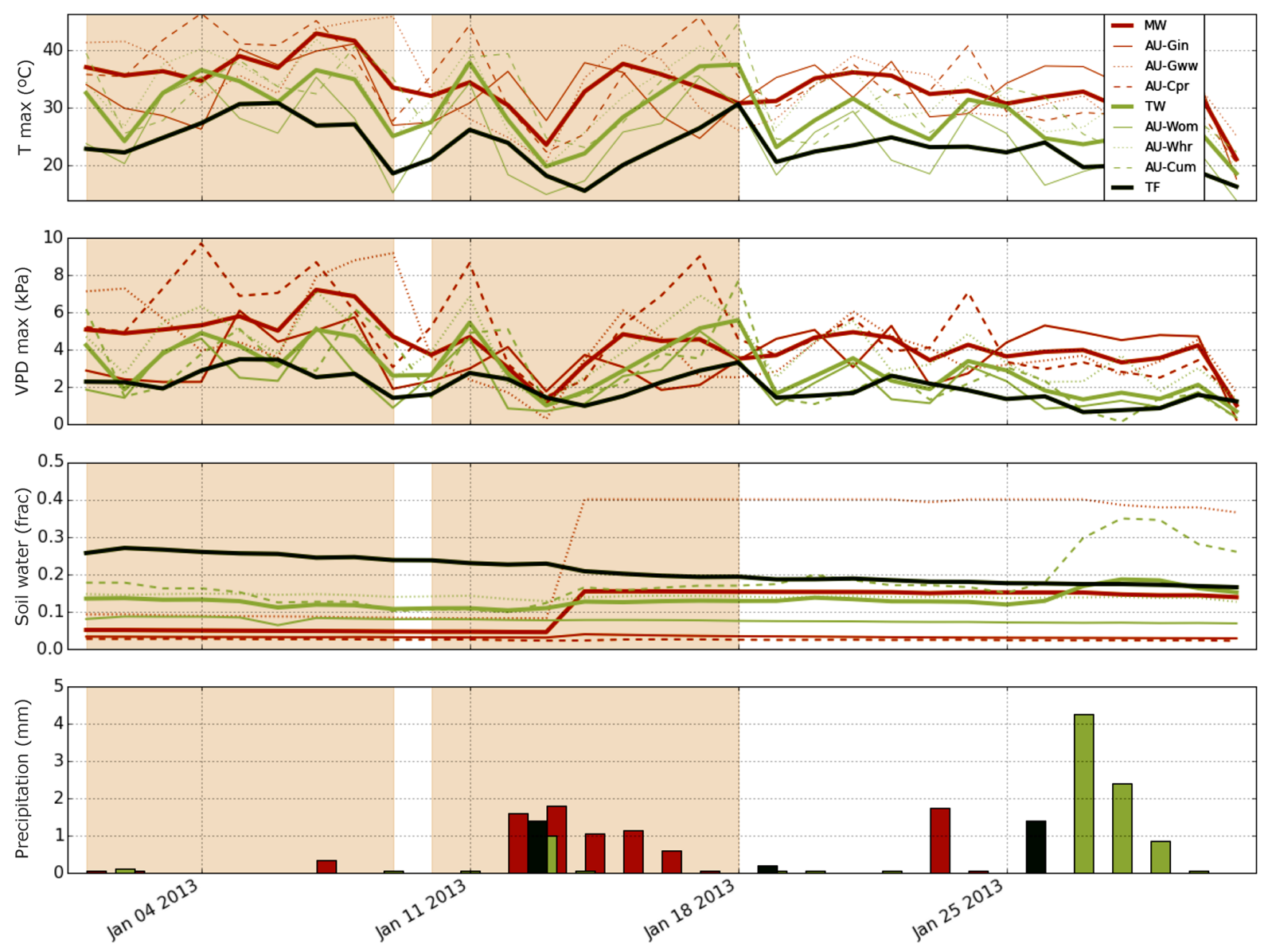

Figure 3. Time series of daily maximum temperature ( $T$ max, top panel), daily maximum vapour pressure deficit (VPD max), soil water content and precipitation. The legend is given in the top panel. Precipitation $(P)$ is given as the average of the daily accumulated precipitation of the sites and displayed for each biome. Shaded areas in the background indicate the time periods HW1 and HW2.

\subsection{Ecosystem response to dry and hot conditions}

\subsubsection{Energy exchange}

Incoming and reflected short-wave radiation were significantly increased by only 70 and $3 \mathrm{~W} \mathrm{~m}^{-2}$ respectively in the energy-limited ecosystem AU-Tum during the first period of the heat wave (Fig. 4, Table 2). Otherwise they remained approximately the same as BGH values except at the MW sites where they were significantly reduced (by
$-62 \mathrm{~W} \mathrm{~m}^{-2}$ ) during HW2 (Table 2). The relatively short duration of the extreme heat wave did not result in changes to albedo (not shown). A warmer atmosphere and potentially increased cloud cover led to a $38 \mathrm{~W} \mathrm{~m}^{-2}$ increase in longwave downward radiation in Western Australia. Due to increased surface temperatures, longwave radiation emitted at the land surface was significantly increased at all sites for both heat wave periods $\left(28 \mathrm{~W} \mathrm{~m}^{-2}\right.$ on average), but more so during HW1 ( $41 \mathrm{~W} \mathrm{~m}^{-2}$ on average). Net radiation was significantly reduced during HW2, but only at MW sites $\left(-35 \mathrm{~W} \mathrm{~m}^{-2}\right)$. 


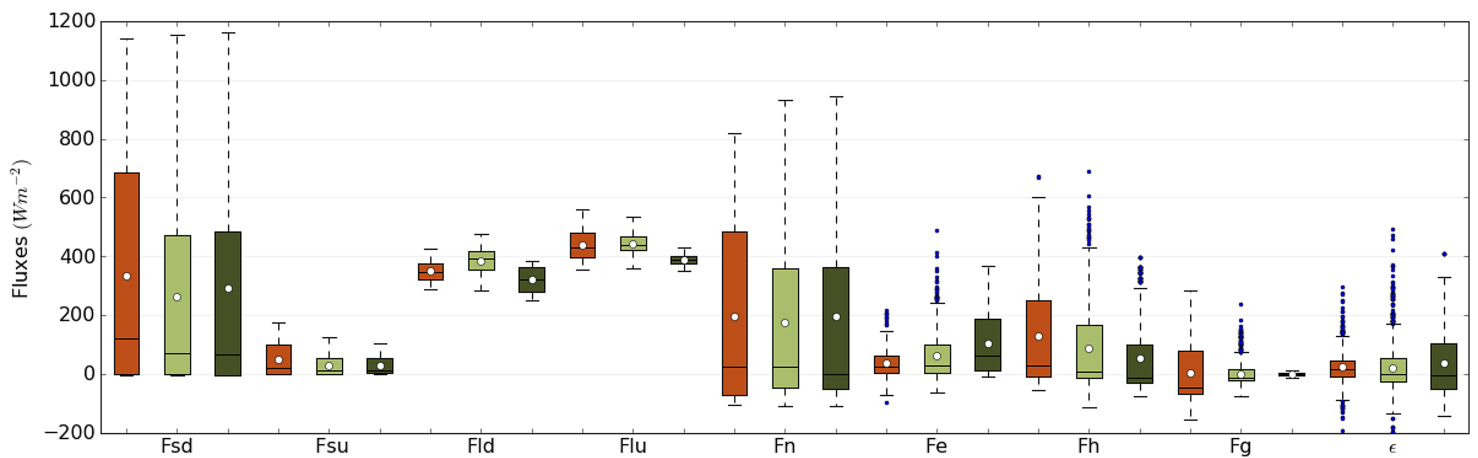

Figure 4. Box plot of energy fluxes for Mediterranean woodlands (MW, red), temperate woodlands (TW, light green) and temperate forests (TF, dark green). Energy fluxes are incoming shortwave radiation (Fsd), reflected shortwave radiation (Fsu), downward longwave radiation (Fld), emitted longwave radiation (Flu), net radiation (Fn), latent heat flux (Fe), sensible heat flux (Fh), ground heat flux (Fg) and energy imbalance $(\varepsilon)$ during the background period BGH (2-6 January 2014). The box extends from the lower to upper quartile values of the data, with a line at the median. The mean value is indicated with a dot. The whiskers extend from the box to show the range of the data. Flier points (outliers, blue dots) are those past the end of the whiskers.
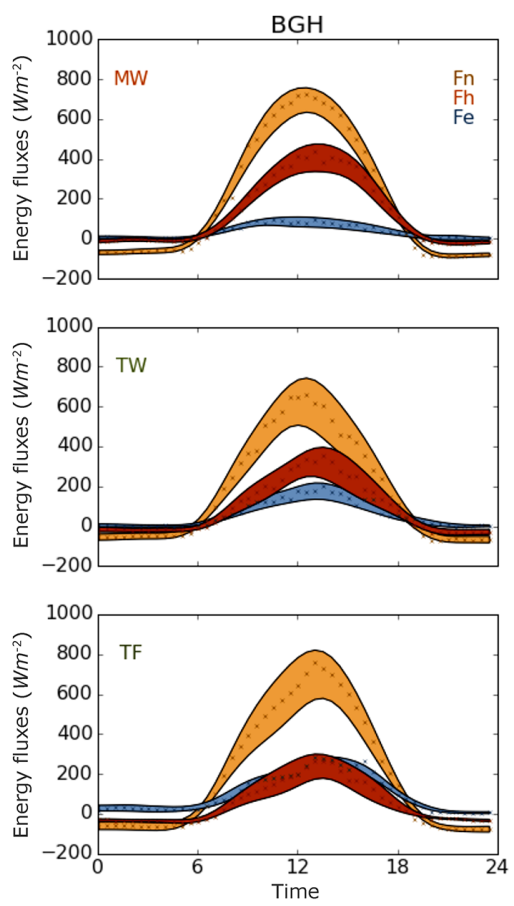
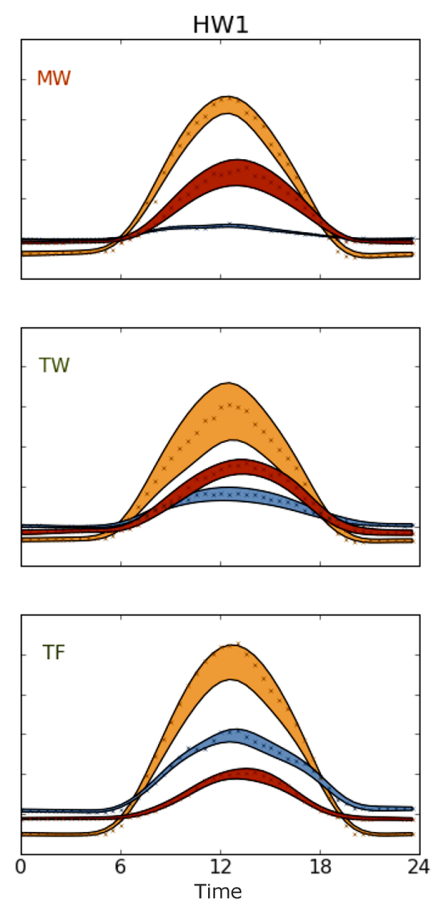

HW2
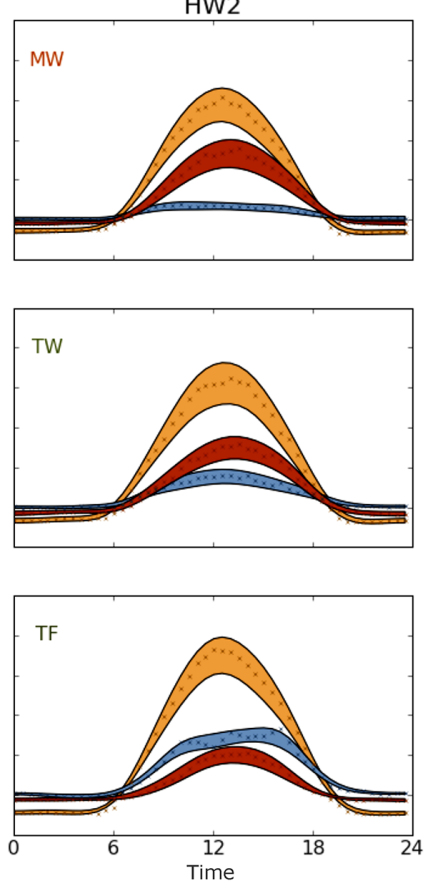

Figure 5. Diurnal course of net radiation (Fn, light amber), sensible (Fh, red) and latent (Fe, blue) heat at the Mediterranean woodlands (MW, top row), the temperate woodlands (TW, middle row) and the temperate forest (TF, lowest row) for the background period BGH (2-6 January 2014), and the first and second period of the heat wave (HW1, 1-9 January 2013; HW2, 10-18 January 2013). Filled areas indicate the range of smoothed \pm 1 standard deviation, average mean values are indicated by symbols.

At all other sites, net radiation was approximately the same during HW1, HW2 and BGH. Available energy (not shown), the energy available to the turbulent heat fluxes, was significantly reduced at MW and TW sites during HW1 (by 25 and $24 \mathrm{~W} \mathrm{~m}^{-2}$ respectively) but was about the same for $\mathrm{HW} 2$. It was also about the same during $\mathrm{HW} 1$ and $\mathrm{HW} 2$ at the TF site.
Figure 5 demonstrates how remarkably different the energy partitioning was at MW, TW and TF sites, as we would expect given their large climatological and biogeographic differences (Beringer et al., 2016). While similar fractions of energy went into latent and sensible heat at the TF site, more energy was directed into sensible heat at TW sites. This energy flux partitioning toward sensible heat was more pro- 

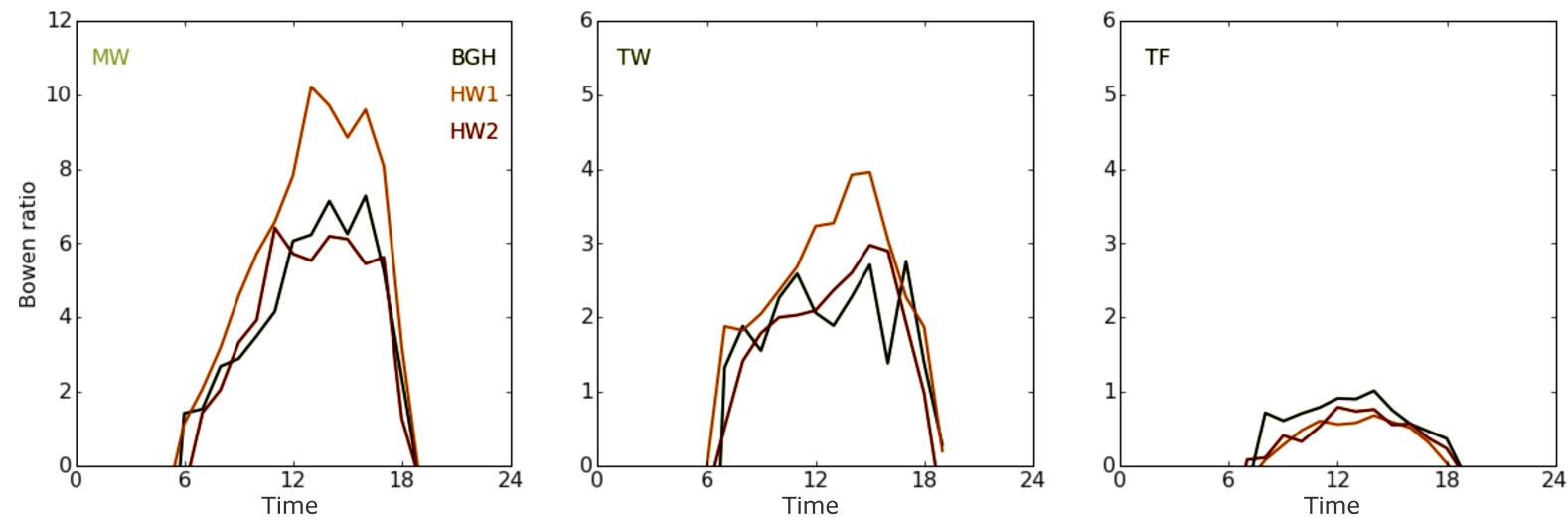

Figure 6. Average daytime Bowen ratio measured over Mediterranean woodlands (MW, left panel), the temperate woodlands (TW, middle panel) and the temperate forest (TF, right panel) for BGH (green line), HW1 (light amber) and HW2 (dark amber).

nounced at MW sites, where both the mean and the variability of latent heat flux were very small due to severe water limitations. Most of the available energy was transferred as sensible heat and hence contributed to the warming of the atmosphere which was also observed for BGH.

During HW1, the generally small latent heat flux at the MW sites $\left(38 \mathrm{~W} \mathrm{~m}^{-2}\right)$ was further reduced by $-12 \mathrm{~W} \mathrm{~m}^{-2}$ (Table 2). During HW2, precipitation temporarily increased water availability, returning latent heat flux to levels observed during BGH. Latent heat flux did not change significantly at TW sites during the HWs compared to BGH conditions. At $\mathrm{TF}$, however, latent heat flux increased by 52 and $14 \mathrm{~W} \mathrm{~m}^{-2}$ during HW1 and HW2 respectively. This was partly due to the very dry conditions in the background period BGH, but daily latent heat flux was also increased compared to the climatology (BGC, Fig. A2 in Appendix A), particularly during HW1.

With values exceeding 7 , the observed ratio of sensible to latent heat, the Bowen ratio ( $\beta$, Bowen, 1926), was very large in the Mediterranean woodlands (Fig. 6). Typical values for $\beta$ reach 6 for semi-arid to desert areas (e.g. Oliver, 1987; Beringer and Tapper, 2000). During the heat wave these values were larger than 10 . With rainfall and increased latent heat flux, $\beta$ decreased to below background conditions in HW2 (6.4) across the MW sites. At TW, $\beta$ was higher than background values during HW1 (reaching a maximum value of 4.0) but decreased to background values during HW2 (2.8). For the TF site, $\beta$ was lower (0.7 and 0.8 during HW1 and HW2 respectively) than during the background period (1.0). It increased steadily in the morning, declined toward the evening and was quite symmetric, while in TW $\beta$ increased strongly in the afternoon during the heat waves. This increase of $\beta$ toward the afternoon hours was observed in MW during all time periods (including BGH).

Measured daily latent heat fluxes and $\beta$ were consistent with flux climatology derived from BIOS2 during the background (BGC; Fig. A1).

\subsubsection{Carbon exchange}

Patterns of carbon fluxes were similar to between-site patterns of energy fluxes (Fig. 7, note differences in $y$ axes). All sites showed that maximum carbon uptake (GPP) occurred in the morning, decreased throughout the afternoon, and mostly increased again in the late afternoon. NEP followed the diurnal course of GPP, with the offset related to total ER. ER increased with temperature and reached a maximum in the early afternoon (not shown). Maximum NEP at MW decreased from $4.16 \mu \mathrm{mol} \mathrm{m}^{-2} \mathrm{~s}^{-1}$ during background conditions to 2.2 in HW1 and $3.3 \mu \mathrm{mol} \mathrm{m}^{-2} \mathrm{~s}^{-1}$ in HW2. Not only did the total amount of carbon uptake decrease, but the number of hours during which the ecosystem was sequestering carbon also decreased from $11.5 \mathrm{~h}$ in background conditions to 10.5 during HW1 and 9.0 in HW2. The same was true in TW and TF in that maximum NEP was lower during the heat wave periods and the time during which the ecosystems acted as sinks was shortened.

Carbon uptake was significantly reduced at MW and TW during HW1 (Fig. 8) with daytime averages decreasing from 4.6 to 3.1 in MW and from 11.2 to $6.2 \mu \mathrm{mol} \mathrm{m}^{-2} \mathrm{~s}^{-1}$ in TW. In TF, however, carbon uptake was increased from 24.2 to $26.5 \mu \mathrm{mol} \mathrm{m}{ }^{-2} \mathrm{~s}^{-1}$ during HW1 and to 27.0 during HW2. Ecosystem respiration increased significantly in both periods of the heat wave and across all ecosystems. Consequently, NEP was significantly reduced at MW and TW sites during both heat wave periods, unchanged at the TF site during HW1, but increased at TF during HW2. During daytime all ecosystems remained carbon sinks during the event but as there were fewer hours and decreased carbon uptake during the day the woodlands switched into carbon sources. Precipitation after HW1 and cooler temperatures during HW2 led to a recovery of the carbon sink in TW during HW2. TF was a strong sink of carbon and remained so during both HW periods. 

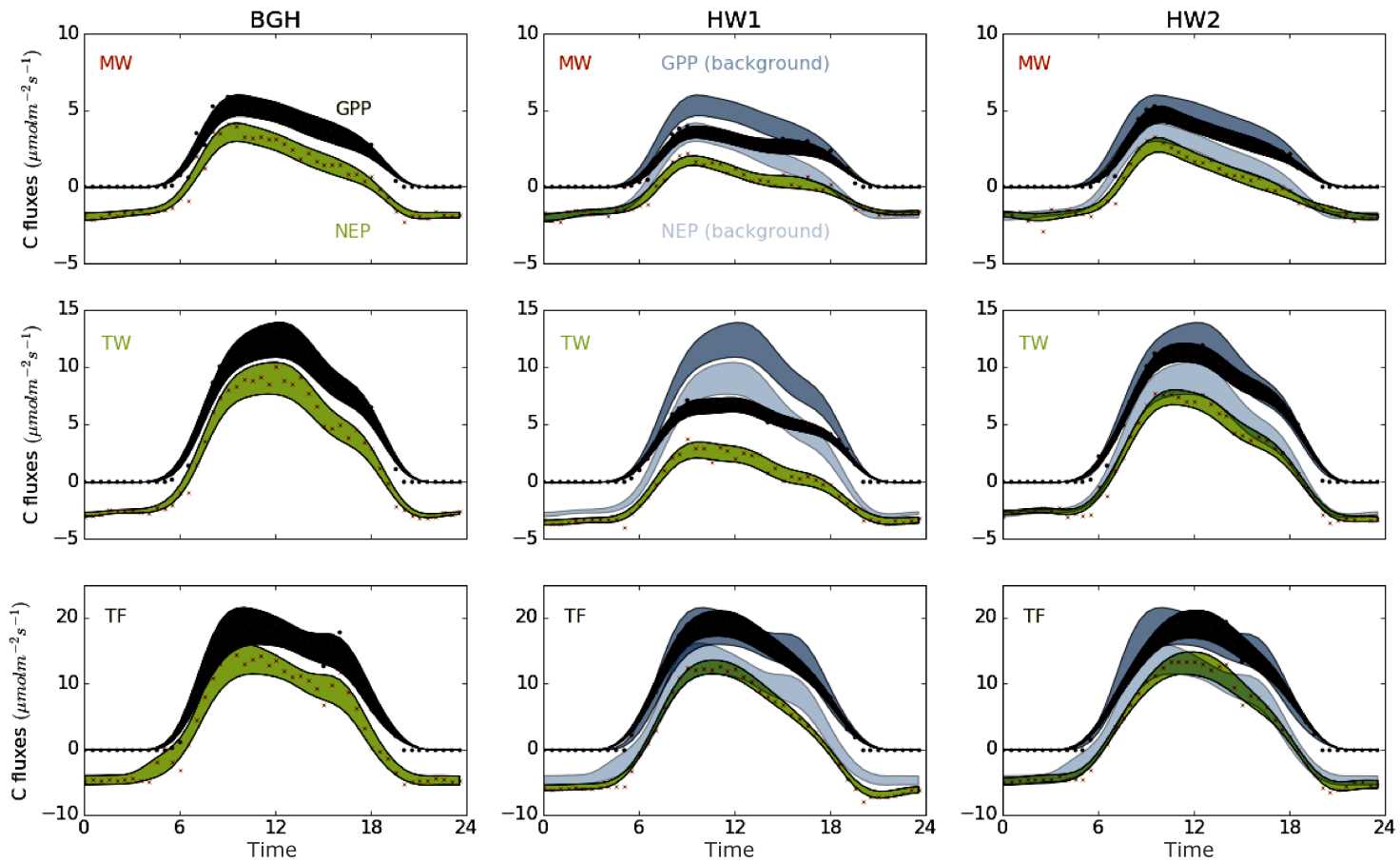

Figure 7. Diurnal course of net ecosystem productivity (NEP, light green) and gross primary productivity (GPP, dark green) at the Mediterranean woodlands (MW, top row), the temperate woodlands (TW, middle row) and the temperate forest (TF, lowest row) for the background period (BHG), and the first and second period of the heat wave (HW1, HW2). Filled areas indicate the range of smoothed \pm 1 standard deviation values, average mean values are indicated by red symbols. Background GPP values (dark grey) and NEP values (light grey) are also plotted in HW1 and HW2 to allow for easier comparison.

Measured GPP and ER showed the same responses in carbon uptake and losses during the heat waves as the flux climatology derived with BIOS2 (BGC, Fig. A2): GPP was reduced during HW1 in woodland ecosystems and increased in the forest during both heat wave periods. ER was increased at all sites and during HW1 and HW2 compared to the longterm climatology.

\section{Discussion}

\subsection{Consequences of Australian heat waves on energy fluxes}

Persistent anticyclonic conditions during the "Angry Summer of 2012/13" led to a heat wave by transporting warm air from the interior of the continent to southern Australia. Such synoptic conditions are the most common weather pattern associated with Australian heat waves (Steffen et al., 2014). However, these weather patterns did not result in increased amounts of available energy at the surface, which was in contrast to heat waves observed in Europe and the USA (see Sect. 4.4). Instead, in our study the energy available for turbulent heat fluxes was similar to or even smaller than background conditions. Background conditions over Australia tend to have large available energy fluxes, even during very cyclonic periods (e.g. the 2010-2011 fluvial; Cleverly et al., 2013). Thus, differences in latent and sensible heat fluxes at the Australian sites used in this study were due to anomalous temperature and soil moisture content rather than to changes in available energy.

During the heat wave, available energy preferentially increased sensible heat flux and led to a subsequent increase of $\beta$ at drier sites (MW and TW) while at the TF site, available energy preferentially increased latent heat flux. The diurnal cycle of $\beta$ at the MW sites generally showed an increase of $\beta$ toward the afternoon hours. This increase was more pronounced during the heat wave periods than during $\mathrm{BGH}$, indicating stress-induced reduction of stomatal conductance (Cowan and Farquhar, 1977). At TW sites, $\beta$ only had a pronounced asymmetry during heat waves, clearly showing stronger stomatal control than during background conditions. At the TF site, $\beta$ was lower during heat waves, but the symmetry in $\beta$ indicates that a decrease in midday stomatal conductance was either counteracted by increased soil evaporation under a steadily increasing humidity deficit with rising temperatures from morning to mid-afternoon (Tuzet et al., 2003), or that there was little stomatal control of the latent heat flux at this site, or a combination of both. Stomatal closure and the associated partitioning of available energy is important as an increased $\beta$ in response to heat waves (MW and 


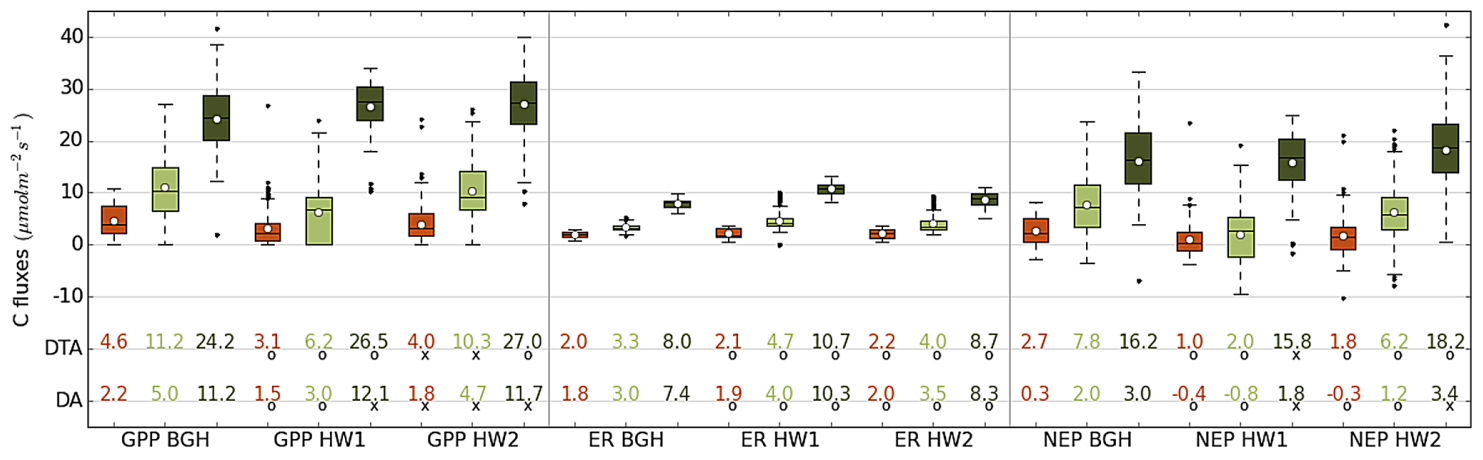

Figure 8. Boxplot of daytime values (09:00-16:00 local standard time) of gross primary productivity (GPP), ecosystem respiration (ER) and net ecosystem productivity (NEP) for the background period (BGH) and the first and second period of the heat wave (HW1, HW2). Daytime average values (DTA) are given below boxes and symbols indicate that they are significantly different from the background period (o) or not (x). Daily averages (DA, 00:00-23:00, local standard time) and their significance are also given. Colours as in Fig. 1.

TW) promotes further heating of the atmosphere, whereas increased latent heat flux suppresses further atmospheric heating (Teuling et al., 2010). This is only possible as long as the latent heat flux is not limited by soil water, particularly during the period of peak insolation (Wolf et al., 2016). At TF the relative extractable water was above a threshold of 0.4 (J. Suzuki, personal communication, 2007) for all but the last two days of the heat wave (not shown), indicating that for most of the time soil water was not limiting the latent heat flux (Granier et al., 1999). Thus, evaporative cooling from latent heat suppressed further heating but depleted soil moisture at the TF site. Eventually, depleted soil water stores can lead to a positive (enhancing) feedback on temperatures as more energy goes into the sensible than the latent heat flux, further amplifying heat extremes by biosphere-atmosphere feedback (Whan et al., 2015). Indeed, the data indicate that toward the end of the heat wave, such positive feedbacks had shifted energy partitioning toward sensible heat flux at all sites.

\subsection{Impact of heat waves on carbon fluxes}

Heat waves and drought can affect photosynthesis (Frank et al., 2015). By means of stomatal regulation, plants exert different strategies to balance the risks of carbon starvation and hydrological failure (Choat et al., 2012). These strategies particularly come into play during extreme events (Anderegg et al., 2012). While the ecosystem response during heat waves is linked to plant stress from excessively high temperatures and increased evaporative demand (i.e. higher vapour pressure deficit), drought stress occurs when soil water supply can no longer meet the plant evaporative demand. The former will lead to reduced carbon uptake through e.g. stomatal closure and disruptions in enzyme activity - the latter can have direct impacts on carbon uptake by reducing stomatal and mesophyll conductance, the activity and concentrations of photosynthetic enzymes (Frank et al., 2015, and ref- erences therein). Apart from these almost instantaneous responses, additional lagged effects can further impact the carbon balance. If high temperatures were to occur in isolation we would expect to observe a decrease in GPP. During the 2012/2013 heat waves in Australia, we observed a diurnal asymmetry in GPP at all sites and in all measurement periods. This is expected in ecosystems that exert some degree of stomatal control to avoid excessive reductions in water potential (e.g. in the afternoon), during higher atmospheric demand and when there is a reduced ability of the soil to supply this water to the roots because of lower matrix potentials and hydraulic conductivity (Tuzet et al., 2003). Daily average carbon uptake at MW and TW was reduced by up to 32 and $40 \%$, respectively. At the TF site, however, daily averaged carbon uptake did not change significantly, and daytime carbon uptake was significantly increased during both periods of the heat wave (see also Fig. 7). This can be explained partly by the very dry conditions during the background period at this site, which could also have caused below average carbon uptake, although comparing the site data against the long-term climatology confirmed an increased carbon uptake during the heat wave (not shown). Although air temperatures clearly exceeded the ecosystem scale optimum of $18^{\circ} \mathrm{C}$ for carbon uptake, and vapour pressure deficit exceeded values of $12 \mathrm{hPa}$, where stomatal closure can be expected at this site (van Gorsel et al., 2013), increased incoming shortwave radiation (Table 2) more than compensated for these factors with increased carbon uptake in this typically energy-limited ecosystem during the heat wave. Overall, we have observed a strong contrast between the water and energy-limited ecosystems with the former (MW and TW) having strongly reduced GPP during heat waves and the latter (TF) having equal or slightly larger GPP.

Heat waves and drought not only affect photosynthesis but also have an impact on respiration (Frank et al., 2015). Increases in ER during the heat wave seem intuitive, given the exponential response of respiration to temperature (e.g. 
Richardson et al., 2006). Drought can also override the positive effect of warmer temperatures and lead to reduced respiration due to water limitations, as observed during the 2003 heat wave (Reichstein et al., 2007) or the 2011 spring drought (Wolf et al., 2013) in Europe. However, during the observed heat waves in Australia, increased air and soil temperatures led to significantly increased ecosystem respiration at all sites, indicating that the thermal response of respiration was undiminished despite soil moisture deficits.

While all sites remained carbon sinks during daytime hours in both heat wave periods, reduced carbon uptake in the woodlands turned them to a net a source of carbon on a daily average. It can hence be concluded that increased ER combined with decreased or unchanged GPP likely turned large areas of southern Australia from carbon sinks to sources. Unlike the Mediterranean woodlands, the temperate woodlands recovered quickly after rain but the response of these ecosystems to a short though intense heat wave indicates that future increases in the number, intensity and duration of heat waves can potentially turn the woodlands into carbon sources, leading to a positive carbon-climate feedback. Heat waves can also induce a transition from energy-limited to water-limited ecosystems (Zscheischler et al., 2015). Transitioning toward water limitation, especially for energy-limited forests, can exacerbate the detrimental effects of extreme events. Recurrent non-catastrophic heat stress can also lead to increased plant mortality, the impact of which would be more evident over longer timescales (McDowell et al., 2008) and as an increase in the frequency of fires (Hughes, 2003). Similarly, legacy or carry-over effects of drought result in increased mortality and shifts in species composition during subsequent years (van der Molen et al., 2011). Future climate change is likely to be accompanied by increased plant water-use efficiency due to elevated $\mathrm{CO}_{2}$ (Keenan et al., 2013), which could lead to more drought and heat-resilient plants, but also to ecosystems with higher vegetation density and thus both higher water demands (Donohue et al., 2013; Ukkola et al., 2015) and a greater susceptibility to large fires (Hughes, 2003). Furthermore, changes in the prevalence of drought will affect forest carbon cycling and their feedbacks to the Earth's climate (Schlesinger et al., 2016). For Australia, there is evidence that semi-arid ecosystems have a substantial influence on the global land carbon sink (Poulter et al., 2014; Ahlström et al., 2015). Due to their impact on the global carbon cycle, predicting the future influence of heat waves and drought on the land sink of Australian woodlands thus remains a key research priority.

\subsection{The effect of intermittent precipitation during the heat wave}

Intervening rain events led to differentiated responses in energy fluxes and lower air temperatures, but soil moisture content remained mostly low during HW2 (see Sect. 3.1). Available energy was significantly lower (compared to BGH) dur- ing HW2 at MW but remained similar at TW and TF. At TF the latent heat flux in HW2 was still enhanced compared to BGH yet smaller than during HW1. Following rainfall the energy partitioning at the MW sites changed toward latent heat flux, with fractions similar to or larger than background conditions. This indicates that soil moisture feedbacks which inhibit warming of the lower atmosphere largely led to a return to standard conditions. At TW, $\beta$ decreased to background values when precipitation occurred. While the magnitude returned to values similar to $\mathrm{BGH}$, there was still a noticeable increase of $\beta$ in the afternoon hours that was more pronounced than under average conditions. An increased fraction of energy going into the latent rather than the sensible heat during HW2 at the drier sites (MW and TW) does not only have important consequences on the soil moisturetemperature feedback but also on ameliorating vapour pressure deficit (Fig. 3) and reducing the atmospheric demand that acts as a stressor on plants (Sulman et al., 2016).

During HW1, the time of maximum carbon uptake at the woodland sites was earlier in the morning than during $\mathrm{BGH}$, and we observed strongly reduced carbon uptake throughout the day. During HW2, however, the shift of maximum GPP toward earlier hours of the day was less pronounced at MW and TW; thus daytime carbon uptake was not significantly reduced. This was in response to the intermittent precipitation and lower temperatures, which led to a reduction in vapour pressure deficit and increased soil water availability. Increased ER at all sites and during both HW periods was dominated by warmer temperatures more than soil moisture limitations. Increased ER combined with decreased or unchanged GPP likely turned large areas of southern Australia from carbon sinks to sources, an effect that was reduced but not offset by the intermittent precipitation.

When carbon losses exceed carbon gains over a long time period (e.g. through increased respiration) mortality can result as a consequence of carbon starvation. Eamus et al. (2013) identified an increased vapour pressure deficit as detrimental to transpiration and net carbon uptake, finding that increased vapour pressure deficit is more detrimental than increased temperatures alone - with or without the imposition of drought. A recent study by Sulman et al. (2016) confirmed that episodes of elevated vapour pressure deficit could reduce carbon uptake regardless of changes in soil moisture. Here, all ecosystems responded with increased carbon uptake to the precipitation events and the associated lower temperatures and vapour pressure deficit. The improved meteorological conditions thus likely decreased the risk of mortality during HW2. As heat waves increase in frequency, duration and intensity in the future (Trenberth et al., 2014), however, we expect a decline in the ameliorating effects of intermittent rain events and an increased risk of mortality. 


\subsection{Comparisons to other heat waves (Europe, North America, China)}

Anticyclonic conditions also caused the intense 2003 European heat wave (Black et al., 2004) as well as the even more intense and widespread heat wave that reached across eastern Europe, including western Russia, Belarus, Estonia, Latvia, and Lithuania in 2010 (Dole et al., 2011). Less cloud cover and more clear sky conditions strongly increased incoming radiation and available energy during the European heat wave and drought in 2003 (Teuling et al., 2010), as well as during the recent drought and heat in California (Wolf et al., 2016), in contrast to the current study. Teuling et al. (2010) observed that surplus energy led to increases in both latent and sensible heat fluxes: over grassland, the energy was preferentially used to increase the latent heat flux, thereby decreasing $\beta$, whereas forest ecosystems generally had a stronger increase in the sensible heat flux and an increase in $\beta$ (Teuling et al., 2010; van Heerwaarden and Teuling 2014). These results highlight the important ecosystem services provided by forests in the long-term, particularly considering the increased prevalence of droughts and temperature extremes projected in the future (Trenberth et al., 2014). The situation in our study was somewhat different in that soil water was only briefly limited in TF, where latent heat flux was mainly driven by temperature and vapour pressure deficit. After an intervening period of precipitation latent heat flux increased at the drier sites (MW, TW) while sensible heat flux decreased or remained the same, potentially breaking the soil moisture-temperature feedback loop in Australia that maintained the heat wave in 2003 Europe. These findings highlight the important role of Australian forest and woodland ecosystems in mitigating the effects of heat waves.

Stomatal control and reductions in GPP at the dry sites (MW and TW) were consistent and of similar magnitude with observations made during e.g. the 2003 European heat wave (Ciais et al., 2005), the 2010 European heat wave (Guerlet et al., 2013), the 2012 US drought (Wolf et al., 2016) and the 2013 heat wave and drought that affected large parts of southern China (Yuan et al., 2015). During these heat waves and droughts, carbon uptake was strongly reduced in general and biosphere-atmosphere feedbacks from reduced vegetation activity further enhanced surface temperatures. This contrasts with the wet site (TF), where local drought effects were observed only toward the end of the study. We found that the response of carbon fluxes of Australian woodland (dry) ecosystems were similar to comparable heat waves on other continents, whereas the detrimental effects of the heat wave were largely ameliorated in wet, energy-limited Australian ecosystems.

Temperature anomalies during the 2012/2013 heat wave in Australia were less extreme ( $\leq-2 \sigma$, Fig. 2$)$ than during the 2010-2011 heat waves in Texas and Russia $(-3 \sigma)$ and the 2003 European heat wave ( $>2 \sigma$; Hansen et al., 2012; Bastos et al., 2014), which resulted in smaller ecosystem re- sponses than in Europe (Reichstein et al., 2007). However, this does not imply that Australian heat waves are less severe than their Northern Hemisphere counterparts because background variability in climate, weather and ecosystem productivity are larger in Australia due to periodic synchronisation of El Niño-Southern Oscillation, the Indian Ocean dipole and the state of the southern annular mode (Cleverly et al., 2016a). When these climate modes are in phase, continental heat waves are strongly related to drought and reduced soil water content, although not to the same extent as in Europe during 2003 (Perkins et al., 2015). Nonetheless, responses of Australian vegetation to heat waves and drought are consistent with vegetation responses elsewhere. For example during the 2003 European heat wave, productivity in grasslands was most sensitive to heat and drought, while open shrublands and evergreen broadleaf forests (like those in our study) were the least sensitive (Zhang et al., 2016). Two-thirds of the productivity in Australia is due to $\mathrm{CO}_{2}$ uptake in nonwoody ecosystems (Haverd et al., 2013a, b), and it was indeed the semi-arid grasslands that produced the extraordinary $\mathrm{CO}_{2}$ source strength during the drought and heat wave of January 2013 (Cleverly et al., 2016b). Similarly, the semiarid Mulga woodlands responded to the 2012/2013 heat wave with a large net source strength, increase in ecosystem respiration and afternoon depression in GPP (Cleverly et al., 2016b). We demonstrated in this study that eucalypt forest and woodland ecosystems of southern Australia were more sensitive to heat waves if those ecosystems also experience moisture limitations.

\section{Conclusions}

We have shown that extreme events such as the "Angry Summer" of 2012/2013 can alter the energy balance and therefore dampen or amplify the event. During this event the woodland sites reduced latent heat flux by stomatal regulation in response to the warm and dry atmospheric conditions. Stronger surface heating in the afternoons then led to an amplification of the surface temperatures. Only the forest site AU-Tum had access to readily available soil water and showed increased latent heat flux. The increased latent heat flux mitigated the effect of the heat wave but continuously depleted the available soil water. The generally increased atmospheric and soil temperatures led to increased respiration but unchanged net ecosystem productivity. The woodlands turned from carbon sinks into carbon sources and while the temperate woodlands recovered quickly after rain, the Mediterranean woodlands remained carbon sources throughout the duration of the heat wave. This demonstrates that there is potential for positive carbon-climate feedbacks in response to future extreme events, particularly if they increase in duration, intensity or frequency. 


\section{Appendix A}

We have used measurements of a reference period during the same season but one year after the 2012/2013 heat wave occurred. Ideally we would have used a climatology derived from observations but OzFlux is a relatively young flux tower network. The first two towers started in 2001 and even globally, very few flux towers have been measuring for more than 15 years, which is relatively short compared to typical climatology records of 30 years. To ensure the representativeness of our results we have therefore compared daily data against a climatology derived from BIOS2 output for the time period 1982-2013.

Table A1 shows the agreement between BIOS 2 output for all sites and the time period 1 January to 31 December 2013. Agreement was generally very good, even more so for the latent heat flux than for the carbon fluxes. Carbon fluxes, and more specifically respiration at the dry Mediterranean woodlands, showed stronger disagreement. It is likely that this to some degree reflects nighttime issues with the eddycovariance method (e.g. van Gorsel et al., 2009) and with the partitioning of the measured fluxes. This may also be an indication that the model was underestimating drought-tolerance at these sites. The low modelled carbon uptake corresponded to periods of low soil water. There were long periods when the modelled soil water was below wilting point within the entire root zone of $4 \mathrm{~m}$. Underestimation could occur if roots were accessing deeper water, the wilting point parameter was too high or the modelled soil water was too low, relative to the wilting point.

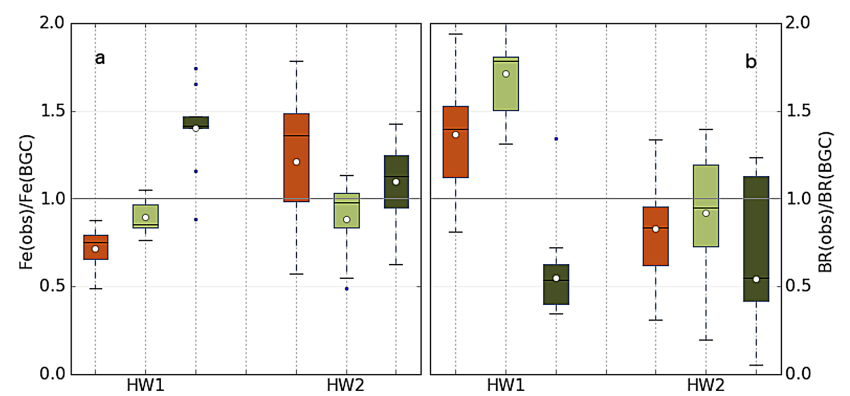

Figure A1. Left panel: boxplot of the ratio of observed latent heat $(\mathrm{Fe}(\mathrm{obs}))$ to the BIOS2 climatology of the latent heat flux (Fe(BGC)) during the first and second period of the heat wave (HW1, HW2). Right panel: same as left but for the Bowen ratio. Colours as in Fig. 1.

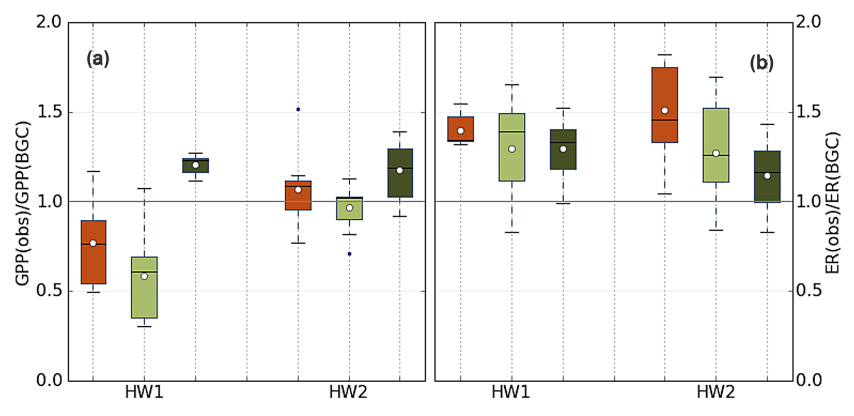

Figure A2. Left panel: boxplot of the ratio of observed gross primary productivity (GPP(obs)) to the climatology of GPP (GPP(BGC)) during the first and second period of the heat wave (HW1, HW2). Right panel: same as left but for the ER. Colours as in Fig. 1.

Figure A1 shows that during HW1 the latent heat flux at the MW and TW sites was reduced. During HW2, precipitation and temporarily increased water availability brought the latent heat flux back to levels observed during BGH for the woodland sites. At the temperate forest, however, the latent heat flux strongly increased, particularly during HW1. Increasingly reduced soil water and lower temperatures reduced the effect during HW2.

Figure A2 shows that carbon uptake was decreased at MW and TW during HW1 and similar to background conditions during HW2. At TF, the forest site, carbon uptake was increased. Respiration (Fig. A2b) was increased at all locations and during both heat wave periods. 
Table A1. Parameters of robust linear model fit between observations and BIOS2 output for all sites, the variables latent heat flux (Fe), gross primary productivity (GPP), ecosystem respiration (ER) and the time interval 1 January-31 December 2013.

\begin{tabular}{|c|c|c|c|c|c|c|c|}
\hline Variable & ID & Coeff. & SE & \multicolumn{2}{|c|}{ [95\% conf. int.] } & RMSE & $r^{2}$ \\
\hline \multicolumn{8}{|l|}{$\mathrm{Fe}$} \\
\hline & AU-Gin & 0.9998 & $5.87 \mathrm{e}-06$ & 1.000 & 1.000 & 27.52 & 0.44 \\
\hline & AU-Gww & 0.9285 & 0.0032 & 0.867 & 0.990 & 23.13 & 0.58 \\
\hline & AU-Cpr & 0.7464 & 0.032 & 0.684 & 0.809 & 15.75 & 0.41 \\
\hline & AU-Wom & 1.1253 & 0.017 & 1.093 & 1.158 & 18.55 & 0.89 \\
\hline & AU-Whr & 0.8917 & 0.031 & 0.830 & 0.953 & 23.66 & 0.42 \\
\hline & AU-Cum & 1.0385 & 0.020 & 0.999 & 1.078 & 28.75 & 0.53 \\
\hline & AU-Tum & 0.8121 & 0.014 & 0.784 & 0.840 & 36.61 & 0.65 \\
\hline \multicolumn{8}{|l|}{ GPP } \\
\hline & AU-Gin & 1.0570 & 0.035 & 0.988 & 1.126 & 1.91 & 0.42 \\
\hline & AU-Gww & 0.3496 & 0.031 & 0.290 & 0.410 & 0.95 & 0.15 \\
\hline & AU-Cpr & 0.2806 & 0.021 & 0.240 & 0.321 & 1.06 & 0.10 \\
\hline & AU-Wom & 1.0176 & 0.015 & 0.988 & 1.047 & 1.53 & 0.81 \\
\hline & AU-Whr & 1.0194 & 0.037 & 0.947 & 1.092 & 2.32 & 0.38 \\
\hline & AU-Cum & 1.8764 & 0.037 & 1.803 & 1.949 & 2.81 & 0.48 \\
\hline & AU-Tum & 0.6667 & 0.006 & 0.655 & 0.679 & 3.20 & 0.88 \\
\hline \multicolumn{8}{|l|}{ ER } \\
\hline & AU-Gin & 1.1687 & 0.043 & 1.084 & 1.253 & 2.20 & 0.13 \\
\hline & AU-Gww & 0.4483 & 0.015 & 0.420 & 0.477 & 0.66 & 0.31 \\
\hline & AU-Cpr & 0.3492 & 0.013 & 0.324 & 0.374 & 0.73 & 0.01 \\
\hline & AU-Wom & 1.2682 & 0.035 & 1.199 & 1.337 & 2.56 & 0.48 \\
\hline & AU-Whr & 1.4227 & 0.039 & 1.347 & 1.499 & 1.87 & 0.14 \\
\hline & AU-Cum & 2.0017 & 0.031 & 1.941 & 2.063 & 2.62 & 0.66 \\
\hline & AU-Tum & 0.8770 & 0.013 & 0.852 & 0.902 & 1.69 & 0.77 \\
\hline
\end{tabular}


Acknowledgements. This work utilised data from the OzFlux network which is supported by the Australian Terrestrial Ecosystem Research Network (TERN; http://www.tern.org.au) and by grants funded by the Australian Research Council. We would like to acknowledge the contributions Ray Leuning made to OzFlux and $\mathrm{Au}$-Tum. Ray Leuning has been cofounder and leader of the OzFlux community and has been a great mentor to many in our network. We would also like to acknowledge the strong leadership role that Helen Cleugh had over many years. The network would not be where it is without their input. Víctor Resco de Dios and Elise Pendal acknowledge the Education Investment Fund and HIE for construction and maintenance of the AU-Cum tower. The Australian Climate Change Science Program supported contributions by Eva van Gorsel and Vanessa Haverd, and Sebastian Wolf was supported by the European Commission's FP7 (Marie Curie International Outgoing Fellowship, grant 300083) and ETH Zurich. Víctor Resco de Dios acknowledges funding from a Ramón y Cajal fellowship RYC-2012-10970. Natascha Kljun acknowledges funding from The Royal Society UK, grant IE110132. We would further like to acknowledge the referees and their helpful comments, which have helped us to improve the manuscript.

Edited by: M. Reichstein

Reviewed by: three anonymous referees

\section{References}

Ahlström, A., Raupach, M. R., Schurgers, G., Smith, B., Arneth, A., Jung, M., Reichstein, M., Canadell, J. G., Friedlingstein, P., Jain, A. K., Kato, E., Poulter, B., Sitch, S., Stocker, B. D., Viovy, N., Wang, Y. P., Wiltshire, A., Zaehle, S., and Zeng, N.: The dominant role of semi-arid ecosystems in the trend and variability of the land $\mathrm{CO}_{2}$ sink, Science, 348, 895-899, 2015.

Anderegg, W. R. L., Berry, J. A., Smith, D. D., Sperry, J. S., Anderegg, L. D. L., and Field, C. B.: The roles of hydraulic and carbon stress in a widespread climate-induced forest die-off, $\mathrm{P}$. Natl. Acad. Sci. USA, 109, 233-237, 2012.

Abramowitz, G., Gupta, H., Pitman, A. J., Wang, Y. P., Leuning, R., Cleugh, H. and Hsu, H.-L.: Neural Error Regression Diagnosis (NERD): A tool for model bias identification and prognostic data assimilation, J. Hydrometeorol., 7, 160-177, doi:10.1175/JHM479.1, 2006.

Barr, A. G., Richardson, A. D., Hollinger, D. Y., Papale, D., Arain, M. A., Black, T. A., Bohrer, G., Dragoni, D., Fischer, M.L., Gu, L., Law, B. E., Margolis, H. A., McCaughey, J. H., Munger, J. W., Oechel, W., and Schaeffer, K.: Use of change-point detection for friction-velocity threshold evaluation in eddy-covariance studies, Agr. Forest Meteorol., 171, 31-45, doi:10.1016/j.agrformet.2012.11.023, 2013.

Bastos, A., Gouveia, C. M., Trigo, R. M., and Running, S. W.: Analysing the spatio-temporal impacts of the 2003 and 2010 extreme heatwaves on plant productivity in Europe, Biogeosciences, 11, 3421-3435, doi:10.5194/bg-11-3421-2014, 2014.

Beringer, J. and Tapper, N. J.: The influence of subtropical cold fronts on the surface energy balance of a semi-arid site, J. Arid Environ., 44, 437-450, doi:10.1006/jare.1999.0608, 2000.

Beringer, J., Hutley, L. B., McHugh, I., Arndt, S. K., Campbell, D., Cleugh, H. A., Cleverly, J., Resco de Dios, V., Eamus, D., Evans,
B., Ewenz, C., Grace, P., Griebel, A., Haverd, V., Hinko-Najera, N., Huete, A., Isaac, P., Kanniah, K., Leuning, R., Liddell, M. J., Macfarlane, C., Meyer, W., Moore, C., Pendall, E., Phillips, A., Phillips, R. L., Prober, S., Restrepo-Coupe, N., Rutledge, S., Schroder, I., Silberstein, R., Southall, P., Sun, M., Tapper, N. J., van Gorsel, E., Vote, C., Walker, J., and Wardlaw, T.: An introduction to the Australian and New Zealand flux tower network OzFlux, Biogeosciences Discuss., doi:10.5194/bg-2016-152, accepted, 2016.

Bi, D., Dix, M., Marsland, S., O’Farrell, S., Rashid, H., Uotila, P., Hirst, A., Kowalczyk, E., Golebiewski, M., Sullivan, A., Yan, H., Hannah, N., Franklin, C., Sun, Z., Vorralik, P., Watterson, I., Zhou, X., Fiedler, R., Collier, M., Ma, Y., Noonan, J., Stevens, L., Uhe, P., Zhu, H., Griffies, S., Hill, R., Harris, C., and Puri, K: The ACCESS coupled model: description, control climate and evaluation, Aust. Meteorol. Oceanogr. J., 63, 41-64, 2013.

Black, E., Blackburn, M., Harrison, G., Hoskins, B., and Methven, J.: Factors contributing to the summer 2003 European heat wave, Weather, 59, 217-223, 2004.

Bowen, I. S.: The ratio of heat losses by conduction and by evaporation from any water surface, Phys. Rev., 27, 779-787, 1926.

Bureau of Meteorology: Extreme heat in January 2013, Special Climate Statement 43, Melbourne, available at: www.bom.gov. au/climate/current/statements/scs43e.pdf (last access: 30 October 2016), 2013

Chapin, F. S., Woodwell, G. M., Randerson, J. T., Rastetter, E. B., Lovett, G. M., Baldocchi, D. D., Clark, D. A., Harmon, M.E., Schimel, D. S., Valentini, R., Wirth, C.,Aber, J. D., Cole, J. J., Goulden, M. L., Harden, J. W., Heimann, M., Howarth, R.W., Matson, P. A., McGuire, A. D., Melillo, J. M., Mooney, H. A., Neff, J. C., Houghton, R. A., Pace, M. L., Ryan, M. G.,Running, S. W., Sala, O. E., Schlesinger, W. H., and Schulze, E.-D. D.: Reconciling Carbon-cycle Concepts, Terminology, and Methods, Ecosystems, 9, 1041-1050, doi:10.1007/s10021-005-01057, 2006.

Choat, B., Jansen, S., Brodribb, T. J., Cochard, H., Delzon, S., Bhaskar, R., Bucci, S. J., Feild, T. S., Gleason, S. M., Hacke, U. G., Jacobsen, A. L., Lens, F., Maherali, H., Martinez-Vilalta, J., Mayr, S., Mencuccini, M., Mitchell, P. J., Nardini, A., Pittermann, J., Pratt, R. B., Sperry, J. S., Westoby, M., Wright, I. J., and Zanne, A. E.: Global convergence in the vulnerability of forests to drought, Nature, 491, 752-755, 2012.

Ciais, P., Reichstein, M., Viovy, N., Granier, A., Ogee, J., Allard, V., Aubinet, M., Buchmann, N., Bernhofer, C., Carrara, A., Chevallier, F., De Noblet, N., Friend, A. D., Friedlingstein, P., Grunwald, T., Heinesch, B., Keronen, P., Knohl, A., Krinner, G., Loustau, D., Manca, G., Matteucci, G., Miglietta, F., Ourcival, J. M., Papale, D., Pilegaard, K., Rambal, S., Seufert, G., Soussana, J. F., Sanz, M. J., Schulze, E. D., Vesala, T., and Valentini, R.: Europewide reduction in primary productivity caused by the heat and drought in 2003, Nature, 437, 529-533, 2005.

Cleverly, J., Boulain, N., Villalobos-Vega, R., Grant, N., Faux, R., Wood, C., Cook, P. G., Yu, Q., Leigh, A., and Eamus, D.: Dynamics of component carbon fluxes in a semi-arid Acacia woodland, central Australia. J. Geophys. Res.-Biogeo., 118, 11681185, doi:10.1002/jgrg.20101, 2013.

Cleverly, J., Eamus, D., Luo, Q., Restrepo Coupe, N., Kljun, N., Ma, X., Ewenz, C., Li, L., Yu, Q., and Huete, A.: The importance of interacting climate modes on Australia's contri- 
bution to global carbon cycle extremes, Sci. Rep., 6, 23113, doi:10.1038/srep23113, 2016a.

Cleverly, J., Eamus, D., Van Gorsel, E., Chen, C., Rumman, R., Luo, Q., Restrepo Coupe, N., Li, L., Kljun, N., Faux, R., Yu, Q., and Huete, A.: Productivity and evapotranspiration of two contrasting semiarid ecosystems following the 2011 global carbon land sink anomaly, Agr. Forest Meteorol., 220, 151-159, doi:10.1016/j.agrformet.2016.01.086, 2016b.

Cowan, I. R. and Farquhar, G. D.: Stomatal function in relation to leaf metabolism and environment, Integration of Activity in the Higher Plant, Cambridge University Press, Cambridge, edited by: Jennings, D. H., 471-505, 1977.

CSIRO and Bureau of Meteorology: State of the Climate 2014, available at: www.bom.gov.au/state-of-the-climate?documents/ state-of-the-climate-2014_low-res.pdf?ref=button (last access: 30 October 2016), 2014.

Dai, A.: Increasing drought under global warming in observations and models, Nature Climate Change, 3, 52-58, 2013.

Dole, R., Hoerling, M., Perlwitz, J., Eischeid, J., Pegion, P., Zhang, T., Quan, X. W., Xu, T., and Murray, D.: Was there a basis for anticipating the 2010 Russian heat wave?, Geophys. Res. Lett., 38, L06702, doi:10.1029/2010GL046582, 2011.

Donohue, R. J., Roderick, M. L., McVicar, T. R., and Farquhar, G. D.: Impact of $\mathrm{CO}_{2}$ fertilization on maximum foliage cover across the globe's warm, arid environments, Geophys. Res. Lett., 40, 3031-3035, 2013.

Eamus, D., Boulain, N., Cleverly, J., and Breshears, D. D.: Global change-type drought-induced tree mortality: vapor pressure deficit is more important than temperature per se in causing decline in tree health, Ecol. Evol., 3, 2711-2729, doi:10.1002/ece3.664, 2013.

Evans, B. and Lyons, T.: Bioclimatic Extremes Drive Forest Mortality in Southwest, Western Australia, Climate, 1, 36, 2013.

Evans, B., Stone, C., and Barber, B.: Linking a decade of forest declines in southwest, Western Australia to bioclimatic change, Aust. Forest., 76, 164-172, 2013.

Fischer, E. M., Seneviratne, S. I., Vidale, P. L., Lüthi, D., and Schär, C.: Soil Moisture-Atmosphere Interactions during the $2003 \mathrm{Eu}-$ ropean Summer Heat Wave, J. Climate, 20, 5081-5099, 2007.

Frank, D., Reichstein, M., Bahn, M., Thonicke, K., Frank, D., Mahecha, M. D., Smith, P., Velde, M., Vicca, S., Babst, F., Beer, C., Buchmann, N., Canadell, J. G., Ciais, P., Cramer, W., Ibrom, A., Miglietta, F., Poulter, B., Rammig, A., Seneviratne, S. I., Walz, A., Wattenbach, M., Zawala, M. A., and Zscheischler, J.: Effects of climate extremes on the terrestrial carbon cycle: concepts, processes and potential future impacts, Glob. Change Biol., 21, 2861-2880, doi:10.1111/gcb.12916, 2015.

Granier, A., Bréda, N., Biron, P., and Villette, S.: A lumped water balance model to evaluate duration and intensity of drought constraints in forest stands, Ecol. Model., 116, 269-283, 1999.

Guerlet, S., Basu, S., Butz, A., Krol, M., Hahne, P., Houweling, S., Hasekamp, O. P., and Aben, I.: Reduced carbon uptake during the 2010 Northern Hemisphere summer from GOSAT, Geophys. Res. Lett., 40, 2378-2383, doi:10.1002/grl.50402, 2013.

Hansen, J., Sato, M., and Ruedy, R.: Perception of climate change, P. Natl. Acad. Sci. USA, 109, E2415-E2423, doi:10.1073/pnas.1205276109, 2012.
Hanson, C. E., Palutikof, J. P., Dlugolecki, A., and Giannakopoulos, C.: Bridging the gap between science and the stakeholder: the case of climate change research, Clim. Res., 31, 121-133, 2006.

Haverd, V. and Cuntz, M.: Soil-Litter-Iso: A one-dimensional model for coupled transport of heat, water and stable isotopes in soil with a litter layer and root extraction, J. Hydrol., 388, 438455, 2010.

Haverd, V., Raupach, M. R., Briggs, P. R., Canadell., J. G., Davis, S. J., Law, R. M., Meyer, C. P., Peters, G. P., Pickett-Heaps, C., and Sherman, B.: The Australian terrestrial carbon budget, Biogeosciences, 10, 851-869, doi:10.5194/bg-10-851-2013, $2013 \mathrm{a}$.

Haverd, V., Raupach, M. R., Briggs, P. R., Canadell, J. G., Isaac, P., Pickett-Heaps, C., Roxburgh, S. H., van Gorsel, E., Viscarra Rossel, R. A., and Wang, Z.: Multiple observation types reduce uncertainty in Australia's terrestrial carbon and water cycles, Biogeosciences, 10, 2011-2040, doi:10.5194/bg-10-2011-2013, 2013 b.

Haverd, V., Smith, B., and Trudinger, C.: Process contributions of Australian ecosystems to interannual variations in the carbon cycle, Environ. Res. Lett., 11, 054013, doi:10.1088/17489326/11/5/054013, 2016.

Hsu, K., Gupta, H. V., Gao, X., Sorooshian S., and Imam, B.: SelfOrganizing Linear Output (SOLO): An artificial neural network suitable for hydrological modeling and analysis, Water Resour. Res., 38, 1302, doi:10.1029/2001WR000795, 2002.

Hughes, L.: Climate change and Australia: Trends, projections and impacts, Aust. Ecol., 28, 423-443, 2003.

IPCC: Climate Change 2013: The Physical Science Basis, Contribution of Working Group I to the Fifth Assessment Report of the Intergovernmental Panel on Climate Change edited by: Stocker, T. F., Qin, D., Plattner, G.-K., Tignor, M., Allen, S. K., Boschung, J., Nauels, A., Xia, Y., Bex, V., and Midgley, P. M., Cambridge University Press, Cambridge, UK and New York, USA, 2013.

Isaac, P: FluxNet Data OzFlux: Australian and New Zealand Flux Research and Monitoring hdl:102.100.100/14247, 2015.

Isaac, P., Cleverly, J., McHugh, I., van Gorsel, E., Ewenz, C., and Beringer, J.: OzFlux Data: Network integration from collection to curation, Biogeosciences Discuss., doi:10.5194/bg-2016-189, in review, 2016.

Karoly, D., England, M., and Stiffen W.: Off the charts: Extreme Australian summer heat, Report by the Climate Commission, available at: http://climatecommission.angrygoats.net/ report/off-charts-extreme-january-heat-2013/ (last access: 30 October 2016), 2013.

Keenan, T. F., Hollinger, D. Y., Bohrer, G., Dragoni, D., Munger, J. W., Schmid, H. P., and Richardson A. D.: Increase in forest water-use efficiency as atmospheric carbon dioxide concentrations rise, Nature, 499, 324-327, 2013.

King A. D., Karoly, D. J., Donat, M. G., and Alexander, L. V.: Climate change turns Australia's 2013 Big Dry into a year of recordbreaking heat, B. Am. Meteorol. Soc., 95, 41-45, 2014.

Kljun, N., Black, T. A., Griffis, T. J., Barr, A. G., Gaumont-Guay, D., Morgenstern, K., McCaughey, J. H., and Nesic, Z.: Response of Net Ecosystem Productivity of Three Boreal Forest Stands to Drought, Ecosystems, 10, 1039-1055, doi:10.1007/s10021-0079088-x, 2007.

Lee, X., Massman, W., and Law, B. E.: Handbook of micrometeorology, A guide for surface flux measurements and analysis, Kluwer Academic Press, Dordrecht, 250 pp., 2004. 
Leuning, R., Cleugh, H. A., Zegelin, S. J., and Hughes, D.: Carbon and water fluxes over a temperate Eucalyptus forest and a tropical wet/dry savanna in Australia: measurements and comparison with MODIS remote sensing estimates, Agr. Forest Meteorol., 129, 151-173, doi:10.1016/j.agrformet.2004.12.004, 2005.

Leuning, R., Zegelin, S. J., Jones, K., Keith, H., and Hughes, D.: Measurement of horizontal and vertical advection of $\mathrm{CO}_{2}$ within a forest canopy, Agr. Forest Meteorol., 148, 1777-1797, doi:10.1016/j.agrformet.2008.06.006, 2008.

Lewis, S. C. and King, A. D.: Dramatically increased rate of observed hot record breaking in recent Australian temperatures, Geophys. Res. Lett., 42, 7776-7784, 2015.

Matusick, G., Ruthrof, K.,Brouwers, N., Dell, B., and Hardy, G. J.: Sudden forest canopy collapse corresponding with extreme drought and heat in a mediterranean-type eucalypt forest in southwestern Australia, Eur. J. Forest Res., 132, 497-510, 2013.

McDowell, N., Pockman, W. T., Allen, C. D., Breshears, D. D., Cobb, N., Kolb, T., Plaut, J., Sperry, J., West, A., Williams, D. G., and Yepez, E. A.: Mechanisms of plant survival and mortality during drought: why do some plants survive while others succumb to drought?, New Phytol., 178, 719-739, doi:10.1111/j.1469-8137.2008.02436.x, 2008.

Meyer, W. S., Kondrlova, E., and Koerber, G. R.: Evaporation of perennial semi-arid woodland in southeastern Australia is adapted for irregular but common dry periods, Hydrol. Process., 29, 3714-3726, doi:10.1002/hyp.10467, 2015.

Mitchell, P. J., O'Grady, A. P., Hayes, K. R., and Pinkard, E. A.: Exposure of trees to drought-induced die-off is defined by a common climatic threshold across different vegetation types, Ecol. Evol., 4, 1088-101, doi:10.1002/ece3.1008, 2014.

Oliver, J. E.: Bowen Ratio, Climatology, Part of the series Encyclopedia of Earth Science, doi:10.1007/0-387-30749-4_30, 1987.

Perkins, S. E., Argueso, D., and White, C. J.: Relationships between climate variability, soil moisture, and Australian heatwaves, J. Geophys. Res.-Atmos., 120, 8144-8164, doi:10.1002/2015jd023592, 2015.

Pfautsch, S. and Adams, M. A.: Water flux of Eucalyptus regnans: Defying summer drought and a record heat wave in 2009, Oecologia, 172, 317-326, doi:10.1007/s00442-012-2494-6, 2013.

Poulter, B., Frank, D., Ciais, P., Myneni, R. B., Andela, N., Bi, J., Broquet, G., Canadell, J. G., Chevallier, F., Liu, Y. Y., Running, S. W., Sitch, S., and van der Werf, G. R.: Contribution of semiarid ecosystems to interannual variability of the global carbon cycle, Nature, 509, 600-603, 2014.

Raupach, M. R., Briggs, P. R., Haverd, V., King, E. A., Paget, M., and Trudinger, C. M.: Australian Water Availability Project (AWAP): CSIRO Marine and Atmospheric Research Component: Final Report for Phase 3, CACWR technical report, available at: http://www.csiro.au/awap/doc/CTR 013_online_FINAL.pdf (last access: 30 October 2016), 2009.

Reichstein, M., Ciais, P., Papale, D., Valentini, R., Running, S., Viovy, N., Cramer, W., Granier, A., Ogee, J., Allard, V., Aubinet, M., Bernhofer, C., Buchmann, N., Carrara, A., Grunwald, T., Heimann, M., Heinesch, B., Knohl, A., Kutsch, W., Loustau, D., Manca, G., Matteucci, G., Miglietta, G., Ourcival, J. M., Pilegaard, K., Pumpanen, J., Rambal, S., Schapphoff, S., Seufert, G., Soussana, J. F., Sanz, M. J., Vesala, T., and Zhao, M.: Reduction of ecosystem productivity and respiration during the European summer 2003 climate anomaly: a joint flux tower, remote sens- ing and modelling analysis, Glob. Change Biol., 13, 1424-1439, doi:10.1111/j.1365-2486.2006.01224.x, 2007.

Reichstein, M., Bahn, M., Ciais, P., Frank, D., Mahecha, M. D., Seneviratne, S. I., Zscheischler, J., Beer, C., Buchmann, N., Frank, D. C., Papale, D., Rammig, A., Smith, P., Thonicke, K., van der Velde, M., Vicca, S., Walz, A., and Wattenbach, M.: Climate extremes and the carbon cycle, Nature, 500, 287-295, 2013.

Richardson, A. D., Braswell, B. H., Hollinger, D. Y., Burman, P., Davidson, E. A., Evans, R. S., Flanagan, L. B., Munger, J. W., Savage, K., Urbanski, S. P., and Wofsy, S. C.: Comparing simple respiration models for eddy flux and dynamic chamber data, Agr. Forest Meteorol., 141, 219-234, doi:10.1016/j.agrformet.2006.10.010, 2006.

Schär, C., Vidale, P. L., Luthi, D., Frei, C., Haberli, C., Liniger, M. A., and Appenzeller, C.: The role of increasing temperature variability in European summer heatwaves, Nature, 427, 332336, 2004.

Schlesinger, W. H., Dietze, M. C., Jackson, R. B., Phillips, R. P., Rhoades, C. C., Rustad, L. E., and Vose, J. M.: Forest biogeochemistry in response to drought, Glob. Change Biol., 22, 23182328, 2016.

Schotanus, P., Nieuwstadt F. T. M., and de Bruin H. A. R.: Temperature measurement with a sonic anemometer and its application to heat and moisture fluxes, Bound.-Lay. Meteorol., 26, 81-93, 1983.

Seneviratne, S. I., Corti, T., Davin, E. L., Hirschi, M., Jaeger, E. B., Lehner, I., Orlowsky, B., and Teuling, A. J.: Investigating soil moisture-climate interactions in a changing climate: A review, Earth-Sci. Rev., 99, 125-161, 2010.

Sheffield, J., Wood, E. F., and Roderick, M. L.: Little change in global drought over the past 60 years, Nature, 491, 435-438, 2012.

Steffen, W.: Quantifying the impact of climate change on extreme heat in Australia, Report by the Climate Council of Autralia, available at: http://www.climatecouncil.org.au/uploads/ 00ca18a19ff194252940f7e3c58da254.pdf (last access: 30 October 2016), 2015.

Steffen, W., Hughes, L., and Perkins, S.: Heatwaves: hotter, longer, more often, Report by the Climate Council of Autralia, available at: http://www.climatecouncil.org.au/uploads/ 9901f6614a2cac7b2b888f55b4dff9cc.pdf (last access: 30 October 2016), 2014.

Sulman, B. N., Roman, D. T., Yi, K., Wang, L., Phillips, R. P., and Novick, K. A.: High atmospheric demand for water can limit forest carbon uptake and transpiration as severely as dry soil, Geophys. Res. Lett., 43, 9686-9695, doi:10.1002/2016GL069416, 2016.

Sun, Q., Meyer, W. S., Koerber, G. R., and Marschner, P.: Response of respiration and nutrient availability to drying and rewetting in soil from a semi-arid woodland depends on vegetation patch and a recent wildfire, Biogeosciences, 12, 5093-5101, doi:10.5194/bg-12-5093-2015, 2015.

Tanner, C. B. and Thurtell, G. W.: Anemoclinometer measurements of Reynolds stress and heat transport in the atmospheric surface layer, Research and Development Tech. Report ECOM 66-G22-F to the US Army Electronics Command, Dept. Soil Science, Univ. of Wisconsin, Madison, WI, 1969.

Teuling, A. J., Seneviratne, S. I., Stöckli, R., Reichstein, M., Moors, E., Ciais, P., Luyssaert, S., van den Hurk, B., Ammann, C., Bern- 
hofer, C. and Dellwik, E., Gianelle, D., Gielen, B., Grünwald, Th., Klumpp, K., Montagnani, L., Moureaux, C., Sottocornola, M., and Wohlfahrt, G.: Contrasting response of European forest and grassland energy exchange to heatwaves, Nat. Geosci., 3, 722-727, doi:10.1038/NGEO950, 2010.

Trenberth, K. E., Dai, A., van der Schrier, G., Jones, P. D., Barichivich, J., Briffa, K. R., and Sheffield, J.: Global warming and changes in drought, Nature Climate Change, 4, 17-22, 2014.

Tuzet, A., Perrier, A., and Leuning, R.: A coupled model of stomatal conductance, photosynthesis and transpiration, Plant Cell Environ., 26, 1097-1116, 2003.

Ukkola, A. M., Prentice, I. C., Keenan, T. F., van Dijk, A. I., Viney, N. R., Myneni, R. B., and Bi, J.: Reduced streamflow in waterstressed climates consistent with $\mathrm{CO}_{2}$ effects on vegetation, $\mathrm{Na}-$ ture Climate Change, 6, 75-78, 2015.

van der Molen, M. K., Dolman, A. J., Ciais, P., Eglin, T., Gobron, N., Law, B. E., Meir, P., Peters, W., Phillips, O. L., Reichstein, M., Chen, T., Dekker, S. C., Doubkova, M., Friedl, M. A., Jung, M., van den Hurk, B. J. J. M., de Jeu, R. A. M., Kruijt, B., Ohta, T., Rebel, K. T., Plummer, S., Seneviratne, S. I., Sitch, S., Teuling, A. J., van der Werf, G. R., and Wang, G.: Drought and ecosystem carbon cycling, Agr. Forest Meteorol., 151, 765-773, 2011.

van Gorsel, E., Leuning, R., Cleugh, H.A., Keith, H., and Suni, T.: Nocturnal carbon efflux: Reconciliation of eddy covariance and chamber measurements using an alternative to the $\mathrm{u}^{*}$-threshold filtering technique, Tellus B, 59, 1-7, doi:10.1111/j.16000889.2007.00252.x, 2007.

van Gorsel, E., Delpierre, N., Leuning, R., Black, A., Munger, J. W., Wofsy, S., Aubinet, M., Feigenwinter, C., Beringer, J., Bonal, D., Chen, B., Chen, J., Clement, R., Davis, K. J., Desai, A. R., Dragoni, D., Etzold, S., Grünwald, T., Gu, L., Heinesch, B., Hutyra, L. R., Jans, W. W. P., Kutsch, W., Law, B. E., Leclerc, M. Y., Mammarella, I., Montagnani, L., Noormets, A., Rebmann, C., and Wharton S.: Estimating nocturnal ecosystem respiration from the vertical turbulent flux and change in storage of $\mathrm{CO}_{2}$, Agr. Forest Meteorol., 149, 1919-1930, doi:10.1016/j.agrformet.2009.06.020, 2009.

van Gorsel, E., Berni, J. A. J., Briggs, P., Cabello-Leblic, A., Chasmer, L., Cleugh, H. A., Hacker, J., Hantson, S., Haverd, V., Hughes, D. and Hopkinson, C., Keith, H., Kljun, N., Leuning, R., Yebra, M., and Zegelin, S.: Primary and secondary effects of climate variability on net ecosystem carbon exchange in an evergreen Eucalyptus forest, Agr. Forest Meteorol., 182, 248-256, doi:10.1016/j.agrformet.2013.04.027, 2013.

van Heerwaarden, C. C. and Teuling, A. J.: Disentangling the response of forest and grassland energy exchange to heatwaves under idealized land-atmosphere coupling, Biogeosciences, 11, 6159-6171, doi:10.5194/bg-11-6159-2014, 2014.

Wang, Y. P., Law, R. M., and Pak, B.: A global model of carbon, nitrogen and phosphorus cycles for the terrestrial biosphere, Biogeosciences, 7, 2261-2282, 2010.

Wang, Y. P., Kowalczyk, E., Leuning, R., Abramowitz, G., Raupach, M. R., Pak, B., van Gorsel, E., and Luhar, A.: Diagnosing errors in a land surface model (CABLE) in the time and frequency domains, J. Geophys Res., 116, G01034, doi:10.1029/2010JG001385, 2011.
Webb, E., Pearman, G., and Leuning R.: Correction of flux measurements for density effects due to heat and water vapor transfer, Q. J. Roy. Meteor. Soc., 106, 85-100, 1980.

Wesely, M.: Eddy correlation measurements in the atmospheric surface layer over agricultural crops PhD Dissertation, 102 pp., 1970.

Whan, K., Zscheischler, J., Orth, R., Shongwe, M., Rahimi, M., Asare, E. O., and Seneviratne, S. I.: Impact of soil moisture on extreme maximum temperatures in Europe, Weather and Climate Extremes, 9, 57-67, 2015.

Wolf, S., Eugster, W., Ammann, C., Häni, M., Zielis, S., Hiller, R., Stieger, J., Imer, D., Merbold, L., and Buchmann, N.: Contrasting response of grassland versus forest carbon and water fluxes to spring drought in Switzerland, Environ. Res. Lett., 8, 035007, doi:10.1088/1748-9326/8/3/035007, 2013.

Wolf, S., Keenan, T. F., Fisher, J. B., Baldocchi, D. D., Desai, A. R., Richardson, A. D., Scott, R. L., Law, B. E., Litvak, M. E., Brunsell, N. A., Peters, W., and van der Laan-Luijkx, I. T.: Warm spring reduced carbon cycle impact of the 2012 US summer drought, P. Natl. Acad. Sci. USA, 113, 5880-5885, 2016.

Wolf, S., Yin, D., and Roderick, M. L.: Using radiative signature to diagnose the cause of warming associated with the Californian Drought, J. Geophys. Res.-Atmos., in review, 2016.

Yuan, W., Cai, W., Chen, Y., Liu, S., Dong, W., Zhang, H., Yu, G., Chen, Z., He, H., Guo, W., Liu, D., Liu, S., Xiang, W., Xie, Z., Zhao, Z., and Zhou, G.: Severe summer heatwave and drought strongly reduced carbon uptake in Southern China, Scientific Reports-Nature, 6, 18813, doi:10.1038/srep18813, 2015.

Zhang, Y., Xiao, X. M., Zhou, S., Ciais, P., McCarthy, H., and Luo, Y. Q.: Canopy and physiological controls of GPP during drought and heat wave, Geophys. Res. Lett., 43, 3325-3333, doi:10.1002/2016g1068501, 2016.

Zhao, M. and Running, S. W.: Drought-Induced Reduction in Global Terrestrial Net Primary Production from 2000 Through 2009, Science, 329, 940-943, doi:10.1126/science.1192666, 2010.

Zhu, Z., Bi, J., Pan, Y., Ganguly, S., Anav, A., Xu, L., Samanta, A., Piao, S., Nemani, R. R., and Myneni, R. B.: Global Data Sets of Vegetation Leaf Area Index (LAI)3g and Fraction of Photosynthetically Active Radiation (FPAR)3g Derived from Global Inventory Modeling and Mapping Studies (GIMMS) Normalized Difference Vegetation Index (NDVI3g) for the Period 1981 to 2011, Remote Sens., 5, 927-948, doi:10.3390/rs5020927, 2013.

Zimmerman, N. E., Yoccoz, N. G., Edwards, T. C.,Meier, E. S., Thuiller, W., Guisan, A., Schmatz D. R., and Pearman, P. B.: Climatic extremes improve predictions of spatial patterns of tree species, P. Natl. Acad. Sci. USA, 106, 19723-19728, 2009.

Zscheischler, J., Orth, R., and Seneviratne, S. I.: A submonthly database for detecting changes in vegetationatmosphere coupling, Geophys. Res. Lett., 42, 9816-9898, doi:10.1002/2015g1066563, 2015. 